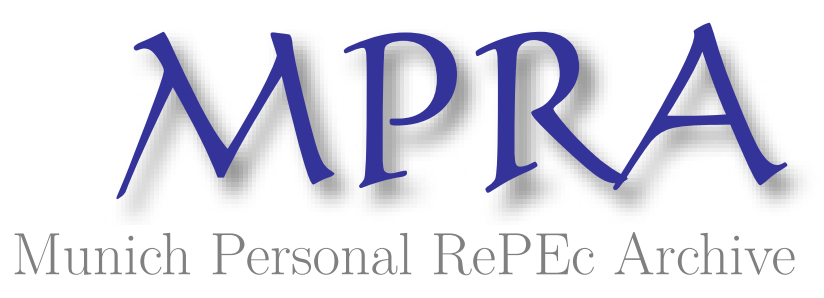

\title{
Financial Reforms and Persistently High Bank Interest Spreads in Bangladesh: Pitfalls in Institutional Development?
}

Hossain, Monzur

February 2010

Online at https://mpra.ub.uni-muenchen.de/24755/

MPRA Paper No. 24755, posted 04 Sep 2010 01:57 UTC 


\title{
Financial Reforms and Persistently High Bank Interest Spreads in Bangladesh: Pitfalls in Institutional Development?
}

\author{
Monzur Hossain * \\ Bangladesh Institute of Development Studies (BIDS) \\ E-17 Agargaon, Sher-E-Bangla Nagar, Dhaka 1207 \\ E-mail: monzur@bids.org.bd
}

\begin{abstract}
This paper analyzes interest rate spreads and margins in banking in Bangladesh for the period 19902008. The application of the Arellano-Bover/Blundell-Bond dynamic panel regression model to a panel of 43 banks for the period 1990-2008 reveals persistency in interest spreads and margins. The model also identifies that high administrative costs, high non-performing loan ratio and some macroeconomic factors are the key determinants of persistently high interest rate spreads and margins. Persistently high spreads and margins in old private banks (established before 1999) are attributed to a certain degree of market power in the post-liberalization period (after 1999). These factors together imply a lack of competition and efficiency in the banking sector of Bangladesh despite financial reforms.
\end{abstract}

JEL Classification: G21, G30, O16

Key Words: Interest rate spread and margin, Bank efficiency, Competitiveness, Bangladesh

\footnotetext{
*Correspondence: Tel: +88-02-8129625; E-mail: monzur@bids.org.bd
} 


\section{Introduction}

Financial reforms and liberalization should improve efficiency in the intermediation process. The interest spread is expected to decline over time as liberalization is accomplished and the financial sector develops. The impact of financial reforms on the commercial banking can thus be better reflected by the behavior of interest rate spreads (IRS) and margins as these are key indicators of financial performance and efficiency of a banking sector. If the spread is large, it works as an impediment to the expansion and development of financial intermediation. Like in many developing countries, interest rate spread has been perceived to be high in Bangladesh since its independence in 1971. The average IRS was estimated to be 6.13 percent in the $1980 \mathrm{~s}, 6.37$ percent in the 1990 s and 5.35 percent in the 2000 s. Since the extent of spread has not changed much in Bangladesh despite financial liberalization in the early $1990 \mathrm{~s}^{1}$ and repeated concerns expressed by the policymakers, there is an element of persistency in spreads. From these concerns, Bangladesh Bank recently adopted interest rate control policy by imposing ceilings on lending and deposit interest rates.

Despite financial reforms, why spreads are persistently high in the Bangladeshi banking sector, and thus the apparent inefficiency? What should be the appropriate policy measures to reduce spreads and make the sector more efficient? This paper attempts to answer these two questions by analyzing the data of 43 banks for the period 1990-2008. Note that interest rate spreads in Bangladesh are comparable to those in other South Asian countries. The average spreads for the last five years was 6.0 percent in Pakistan, 4.95 percent in India and 6.18 percent in Sri Lanka ${ }^{2}$. Thus the Bangladesh case is nothing but a typical South Asian case of maintaining moderate but persistent level of spreads. The business community and policymakers in Bangladesh are therefore concerned more about persistently high level and non-competitive characteristics of spreads. This non-competitive structure of spreads could be an obstacle for sustaining high economic growth that critically depends on an efficient and competitive financial sector.

Our understanding of the determinants of spreads and margins in Bangladesh is limited. There is no comprehensive study available on spreads and margins with a rigorous statistical analysis of bank panel data. This is also a challenging task to analyze spreads and

${ }^{1}$ Banks were free to adjust their own rates since February 19, 1997. Further flexibility in the interest rate was introduced on July 12, 1999 permitting banks to differentiate interest rates to individual borrowers except exporters (Economic Trends, Bangladesh Bank).

${ }^{2}$ Data are obtained from respective country's central bank. 
margins in Bangladesh because of limited information on banking businesses ${ }^{3}$. With such limitations, two recent studies, namely Ahmed and Islam (2006) and Mujeri and Islam (2008) have highlighted some aspects of interest spreads in Bangladesh. This paper attempts to improve our understanding of the spreads and margins in Bangladesh by analyzing: (i) a long bank panel data covering the period 1990-2008, and (ii) time-series aggregate data of interest rates and loans/deposits. A GMM dynamic panel regression model, Arellano-Bover/BlundellBond has been applied to the data to identify the determinants of spreads and margins as well as their persistency. Moreover, this paper analyses long-term behavior of interest rates by employing the Vector Auto Regression (VAR) technique and the Granger-causality test to the aggregate time-series data. Data are collected from commercial banks' balance sheets and income statements that are available in the repository of the Bangladesh Bank.

A wide range of studies identified that large spreads occur in developing countries mainly due to high operating costs, financial taxation or repression, lack of a competitive financial/banking sector and macroeconomic instability (Barajas et al, 1999, Brock and Rojas-Suarez, 2000, Chirwa and Machila, 2004, Beck and Hesse, 2009). These factors can be summarized into four broad categories: (i) the risk factors, (ii) small financial system factor, (iii) market structure, and (iv) macroeconomic factors. Analyzing these factors, this study finds that high administrative costs and high non-performing loan ratios are the main determinants of high spreads and margins in Bangladeshi banks. Market power, which was attributed to the state-owned banks (SCBs) in the pre-liberalization period, has been gradually shifted to old and big private commercial banks (PCBs) in the post-liberalization period.

An important contribution of this study is that it applies the Arellano-Bover/BlundellBond GMM dynamic panel regression model to capture the persistency of spreads and margins by including their lagged values. The results show that both lagged spreads and margins are significant, that is, persistency is an important factor in determining the spreads and margins in Bangladesh. The persistency in spreads and margins, in other way, captures some unobserved characteristics of the banking sector such as managerial revealed preferences, their risk-aversion motive as well as corporate governance problem.

Another interesting feature of this study is that some contrasting results are obtained in explaining factors related to ex-ante interest spread and ex-post interest margins. While

\footnotetext{
${ }^{3}$ In recent days, a growing tendency can be seen among banks to be engaged in capital market businesses through creating merchant banks, mutual funds and individual trading in the stock markets. However, their profits from share-market business are not clearly reported in any of the documents available.
} 
bank size, capital ratio, bank rate and tax rate are not significant to interest rate spread, they are significant to interest margins. These findings are consistent with some cross-country studies (Beck and Hesse, 2009; Demirgüc-Kunt et al., 2004).

In addition, aggregate time-series data analysis reveals the fact that spread is sensitive to deposit rates, not the lending rate, meaning that any shock to spread eventually transmits to the deposit rate. This finding suggests that recently imposed control on the lending rate may not help reduce the level of spread in the medium-to-long run as envisaged by the Bangladesh Bank.

The paper is organized as follows. Section 2 provides a survey of literature on interest rate spreads. Section 3 provides an overview of the banking sector of Bangladesh. Section 4 provides a discussion on the behavior of spreads over time. Section 5 discusses about data and variables and Section 6 provides an analysis of the determinants of spreads and margins using data of a panel of 43 banks for the period 1990-2008. Finally, Section 7 concludes the paper.

\section{Survey of literature}

What are the determinants of spreads and margins? Does financial liberalization decrease the level of spread? These two questions are addressed in most of the studies on interest spreads. A list of studies on the determinants of spreads is given in Table 1 in order to make a quick regional and cross-country comparison. Beck and Hesse (2009) summarize the findings on the determinants of spreads and margins under four broad-based views. First, the risk-based view encompasses some systematic differences across borrowing sectors and deficiencies in the contractual and informational frameworks driving high spreads and margins. Factors such as the bank size, capital ratio, bank liquidity, operating costs, nonperforming loan (NPL) and non-interest income are identified by some studies as the determinants of IRS. Second, the small financial system view focuses on the fixed transaction cost component of financial service provision and the difficulties in exploiting the resulting scale economies. Some studies assess this view by looking at the market share of deposits and/or loans.

Third, the market structure view focuses on the competitiveness of the banking system and the effect of privatization and foreign bank entry. Market concentration ratio is often used to capture monopolistic competition in the sector. Finally, the macroeconomic view 
focuses on exchange rates, interest rate policies, inflation rates and GDP growth as driving interest spreads and margins in the banking system.

All these factors together or partially can contribute to high spreads and margins in a less developed financial system. Are the determinants alike across countries? Interest spreads are fairly higher in developing countries than developed countries. Among developing countries, the level of spread is higher in African and Latin American countries than those in Asian countries. It can be observed from Table 1 that almost similar factors such as management inefficiency, high administrative costs, high non-performing loans, market powers and inflation can explain high spreads across countries. Country-specific characteristics do not seem to have important implications for higher spreads.

Studying the determinants of spreads and margins is meaningful only in a financially liberalized economy. The empirical evidence regarding the impact of financial liberalization on spreads is mixed. While some studies argue that financial liberalization substantially reduces spreads (e.g. Honohan, 1999; Fuentes and Basch, 1997; Denizer, 1999), some other studies find the opposite scenarios (e.g. Barajas et al., 1999; Chirwa and Mlachila, 2004). The contrasting evidence can be explained by the degree of financial reforms, regulatory framework in place, institutional strength and other country-specific factors.

There appears to have some shortcomings in methodologies to study the spread and margin. Various types of regression models including pooled OLS, median least squares, fixed effect (FE) and random effect (RE) panel regression, system equation etc. have been applied. While FE or RE panel regression models suffer from short-panel bias, other regression models mentioned here may not be appropriate to capture some unobserved characteristics of firms, such as managerial risk aversion, revealed preferences, governance structure etc. Ignoring unobserved firm-level heterogeneity imposes incorrect assumption of zero correlation, leading to biased and inefficient estimates. One of the ways to handle the problem is to capture persistency in spreads. A suitable model, particularly a dynamic panel regression model, can be of useful in this regard.

Therefore, it appears that more country-specific and cross-country analysis can contribute to increased understanding of the determinants of interest spreads and margins.

\section{Financial Reforms and Financial Sector Development in Bangladesh: An Overview}

The formal financial sector in Bangladesh, as in other regions of the developing world, essentially consists of banks. Although non-bank financial institutions and stock markets have been developing in Bangladesh, their influence generally remains marginal compared to 
the banking sector. The banking sector comprises of 48 banks including 4 state-owned banks (SCBs), 30 private commercial banks (PCBs), 5 specialized banks (SBs) and 9 foreign commercial banks (FCBs). Bangladeshi banks have been operating in a sound and stable macroeconomic environment for the last two decades. During this period, Bangladesh registered 5 to 6 percent GDP growth with annual inflation rate ranges between 2 to 9 percent. The expectation is high on the banking sector as Bangladesh is envisioned to be a middle income country by 2020 .

Prior to reforms started in the 1990s, banks were mostly government-controlled and political imperatives were consistently given priority over commercial viability. Competition between banking institutions remained stifled and banks had little incentive to develop their activities. As a result, the institutional capacity of banks to manage the systemic and idiosyncratic risks in financial systems has failed to develop sufficiently. In part to remedy these problems, Bangladesh underwent financial sector reforms in the early 1990s. These reforms, which were part of a broader set of market-oriented, often donor-led reforms, generally entailed financial liberalization and institutional reforms to prudential regulation systems and distressed government-owned banks. They have succeeded in limiting the scope of government intervention in the financial sector and in strengthening prudential regulation of financial institutions. Mostly, however, they have not succeeded in significantly deepening or diversifying the financial sector.

In fact, competition has not increased significantly and the banking sector in Bangladesh still appears to be oligopolistic. With liberalization toward a market oriented interest rate policy under the Financial Sector Reform Program (FSRP) in the 1990s, the banks were allowed to set lending and deposit interest rates within bands set by Bangladesh Bank; later the bands were removed allowing the banks to set interest rates along the lines of market conditions. Finally, other restrictions were removed in 1999 enabling the banks to enjoy greater flexibility in setting interest rates. As Table 2 shows, the dominant role of SCBs' has started declining since 1999.

SCBs' share in total assets has decreased from 54 percent in 1998 to 31 percent in March, 2009. Private banks' (including foreign banks) share rose from 33 percent in 1998 to 63 percent in 2009. In 2008, the ratio of liquid liabilities (M3) to GDP, an indication of the monetary resources mobilized by the formal financial sector, was 55 percent in Bangladesh, compared with 49 percent in East Asia and the Pacific, and 100 percent in high-income countries. In 2008, private sector credit as a ratio of GDP, a key to the intermediary 
performance of the financial sector, was 55 percent in Bangladesh, compared with 30 percent in South Asia and 107 percent in high-income countries (Honohan and Beck, 2007).

Table 3 presents some indicators of financial development, which display steady increasing trend, indicating widening and deepening of the financial system in Bangladesh over time. It is also observed that the average credit, deposit and broad money to GDP ratios increased substantially from 6.6 percent, 14.9 percent and 19.0 percent respectively over 1976-1980 to 28.8 percent 35.01 percent and 40.0 percent respectively over 2001-2005. Investment as a percent of GDP and per capita income (in current USD) also displays a similar pattern and move broadly together reflecting a close association among financial development, investment and per capita income during the period.

Banking sector of Bangladesh, particularly state-owned banks (SCBs), suffer from high non-performing loans (around 30\% for SCBs in 2008). Contract enforceability is often weak in Bangladesh, making legal recourse against defaulting borrowers an uncertain, lengthy and costly exercise, which contributes to high non performing loans. The low risk-management capacity of banks in Bangladesh is in large part due to the legacy of pervasive state interventionism in the financial sector.

Table 4 presents different types of interest rates for the period 2004 to 2008 (yearly average). It is observed that interest rates on trade financing, working capital and consumer loan remained higher than the other types of advances. Higher interest rates on working capital and trade financing eventually affect private investments. On the other hand, savings rates remained fairly stable ranging between 5 and 6 percent during the period under consideration, but fixed deposit rates showed an increasing trend. Despite high interest rates, non-interest income (e.g. commission and fees) is substantially higher for Bangladeshi banks, particularly for FCBs (Figure 2). This high non-interest income may lead banks to continue with high spreads and margins.

To understand the market structure, the market concentration ratios are estimated by the Herfindahl-Hircshman Index (HHI) for deposits and loans, which are plotted in Figure 3. Both indices indicate that market power has been gradually shifted from SCBs to PCBs after liberalization. After 2004, PCBs concentration ratio for loans and deposits has crossed SCBs ratios. Since the PCBs HH index hovers around 4000 in 2008 with an increasing trend, a monopolistic competition is expected to prevail in the banking system of Bangladesh.

\section{Understanding interest rate spreads in Bangladesh}

\subsection{Interest rate spreads and margins}


The interest rate spread or margin can be defined in many ways. In a narrow definition, the spread is calculated by taking difference between the weighted average loan rate and weighted average deposit rate for each bank and each year, where the weights are the relative amounts of loans or deposits contracted at specific interest rates in the respective year and by the respective bank. Under a wide definition, the net interest margin is defined as the difference between total interest and commission received over total earning assets and total interest paid minus fees over total interest bearing liabilities.

Estimated spreads and margins are plotted in Figure 4A and 4B respectively. While spread shows a declining trend in the case of PCBs, an increasing trend is apparent in the cases of SCBs and SBs. For PCBs, spread was estimated to be lower than 5 percent after 2004, but it is higher than 5 percent for other banks. A Bangladesh Bank statistics showed that spread is the highest for FCBs $(8.83 \%)^{4}$. Interest margin showed an increasing trend except a dip in 2007 due to global recession. FCBs enjoy higher margins than their counterparts.

\subsection{Correlation between spreads and loans/deposits}

Table 5 provides a correlation analysis between spreads and its components, such as deposits and loans. Before 1999, the spreads were found to be positively correlated with the loan rate and negatively with the deposit rate except for SBs. After 1999, in the case of PCBs, spread is found to be positively correlated with large loan and working capital loan rates but negatively with savings deposit rates, leaving fixed deposit rate uncorrelated. In the case of SCBs, spread is found to be correlated (negatively) only with savings deposit rates. For SBs, IRS is perfectly correlated with large loan rate. An important implication of the correlations is that any shock that results in an increased spread will probably raise the lending rate of large loans or decrease the deposit rate. This is consistent with the characteristics of banking in Latin America in the 1990s (see Brock and Suarez, 2000).

\subsection{The behavior of spreads across time and across banks}

The variation in interest rate spreads is found to be larger in PCBs than in SCBs with an increasing trend, particularly after 1999 (Table 6). Though the variation over time is less than 1 percent, an increasing trend of variation in spreads after 1999 can be explained explicitly by financial liberalization measures.

\footnotetext{
${ }^{4}$ It was not possible for us to estimate the weighted average IRS for the FCBs due to unavailability of their data on loans and deposits. Some of the FCBs do not even publish annual reports; they just send their performance report to the respective departments of the Bangladesh Bank.
} 


\subsection{Long-term behavior of the IRS}

From the analysis of correlation and variation, it is not possible to understand the long-term dynamics of spreads. Therefore, the Granger-causality test and VAR analysis are performed to understand the long-term behavior of spreads and its components.

\subsubsection{Granger-causality Test}

The Granger causality test refers to the effects of past values of one variable on the current value of another variable. The purpose of performing Granger Causality test is to examine whether the change in spreads is associated with deposit rate or loan rate as well as whether respective interest rates are sensitive to interest bearing deposits or loans. Table 7 (Panel A) presents the results on Granger-causality test for spreads and deposit rates and Table 7 (Panel B) presents results on the causality test between spreads and lending rates. The results indicate that the change in spread is associated with a change in deposit rate, not with a change in lending rate. This implies that any shock to spread is supposed to translate to deposit rate in the long run. An important policy implication of this finding is that any ceiling on the lending rate, which is now in place, may not help reduce the spread in the long run, albeit it may work in the short run.

Table 8 shows that the amount of both loans and deposits does not matter for their respective interest rates. This could be an indication of non-competitive structure of the banking system of Bangladesh. Moreover, the insensitivity of interest rates with the amount of loans/deposits helps banks keep interest rate spread persistently high. This is an indication of a small financial system with lack of depth and alternative saving/lending instruments.

\subsubsection{Impulse Responses}

An impulse response analysis with the Vector Auto Regression (VAR) is shown in Figure 5. The forecast error variance decomposition tells us the proportion of the movements in a sequence due to its "own" shocks versus shocks to other variables. In Figure 5, Panel A shows the movements between deposit interest rates (ID) and lending interest rates (IL) and their response to each other. Considering 1990 as the initial year, it shows that after 2000 any shock to IL has almost translated to ID as their convergence is rapid. This leads to the conclusion that there has been a tendency among Bangladeshi commercial banks to keep the spread unchanged. Moreover, Panels B and C show that the amount of loans (LLOAN) and deposits (LDEPOS) is not responsive to respective interest rates. This indicates that any ceiling on lending interest would therefore contribute to the reduction in deposit interest rates. The aggregate data analysis indicates that the money market has not yet turned to be 
competitive.

To summarize the findings of this section, any change in spreads is caused by a change in deposit rates, not the lending rates (long-term perspective). After 2000, any shock to lending rates seemed to be translated quickly to deposit rates ${ }^{5}$. In addition, the amount of loans and deposits is not found to be responsive to their respective interest rates, indicating that banking sector in Bangladesh is not competitive in a sense that they are not competing among themselves for deposit mobilization as well as for exploring lending opportunities.

\section{Data and Variables}

The bank balance sheet data of 43 banks for the period between 1990 and 2008 are used for the analysis ${ }^{6}$. An unbalanced panel of commercial banks' interest spreads is used to identify the determinants of interest rate spreads and margins in Bangladesh. Explanatory variables include variables representing risk factor, market structure, small financial system, and macroeconomic factors suggested by the literature.

The factors that may reflect risk-taking behavior of banks are the bank size, capital ratio, bank liquidity, operating costs, non-performing loans (NPL), and non-interest income. The logarithm of total asset is used as a measure of bank size. Bank size can be a proxy of inefficiency if it is not managed properly, thereby lead to high spreads. Non-interest income implies the ratio of commission, fees etc. over interest income. It is likely that banks that have higher non-interest income have less incentive to reduce spread. Table 9 shows that non-interest income is about 26 percent of interest income.

Overhead cost is the ratio of administrative costs to total assets. Banks with higher operating costs are expected to have higher interest spreads. High overhead cost may result from inefficiency in bank operations that may be shifted to bank customers. Bank liquidity is defined as the ratio of total operational assets to total bank liabilities. This variable is expected to be negatively related to interest spread. An increase in liquidity reduces the bank liquidity risk, which reduces the interest spread due to a lower liquidity premium charged on loans. Capital ratio is defined as the ratio of shareholders' equity to total assets. Saunders and Saunders and Schumacher (2000) provide evidence of the positive and generally significant relationship between spreads and capital ratios in developed countries. For developing

\footnotetext{
${ }^{5}$ This observation is commendable because it indicates that the current policy of interest rate cap on the lending rates would not help reduce the IRS in the long run, rather it might work in the short run. This has already become clearer as the banks are reducing their deposit rates with lending interest cap at 13\% to keep the spread almost the same as it was before the cap-regime.

${ }^{6}$ Data are not available for all banks for all the years. Because some banks enter newly in different periods and some banks merged with another one. Moreover, all the required data are not available in banks' balance sheet particularly for the period before 1999. So this is an unbalanced panel data.
} 
countries, if there are limited channels for raising capital, such as thin or underdeveloped equity markets, banks will be in a strong position to keep the IRS high. Thus, the capital ratio is expected to be negatively associated with the IRS. Since liquidity is highly correlated with spread, only capital ratio enters into the model.

Historically, Bangladeshi banking sector is characterized by high non-performing loans, majority given out by state-owned banks. Although private banks have on average 5 percent NPL of their total loans, the ratio is still around 20 percent for SCBs (Table 9). Banks tend to offset the cost of screening and monitoring due to bad loans and/or the cost of foregone interest revenue by charging higher lending rates (Barajas et al., 1999). Randall (1998), and Brock and Rojas-Suarez (2000) find support for the positive and significant association between spreads and NPL.

The market share for deposits and loans is used to assess small financial system view of interest rate spread. The market share of deposits (MSD) is the share of individual bank's deposit in a year in terms of total deposits including deposits in banks, non-banks, postal deposits and national savings directorate (NSD) ${ }^{7}$ certificate. The market share of loan is the share of individual bank's loans to total loans (both banks and non-banks) in a year. Both the deposit and loan share are found to be almost the same, around 2 percent. However, it is 9 percent for SCBs and 1 percent for PCBs (Table 9). Historically, SCBs have been dominating in the share of both deposits and loans in Bangladesh. The variable MSD has of particular importance to capture the impact of NSD on spreads, as many argue that higher interest rate in NSD creates problems for banks to reduce the lending rate or the IRS. Although the market share and thus relative size can be a proxy for size, it also proxies for the relative market power of different banks. While a negative relationship between market share and interest rate spreads predicts the small financial system view, a positive relationship would predict a monopolistic/oligopolistic market structure.

Several variables, such as financial liberalization index (FLI) indicating a dummy (1 for year 1999 onward, 0 otherwise), and Herfindahl-Hircshman index (HHI) for loans are used to assess the impact of market structure on the IRS. Among macroeconomic factors, quantum index of production (QI), inflation, liquidity reserve requirement (LRR) and corporate income tax rate (Tax) are considered as potential determinants of the spreads and margins.

\footnotetext{
${ }^{7}$ The National Savings Directorate (NSD) certificates are the principal devices of public (non-bank) borrowing for financing budget deficit. The interest rate on 3-year NSD certificate has been $11.5 \%$ while the same on 5-year certificate is $12 \%$. These savings rates are higher than those are offered by banks.
} 
Table 10 provides correlations between the variables concerned. In most cases, the correlations between spread and employed variables show a positive and significant relationship, but far from perfect correlation.

\section{Determinants of spread and margin: methodology and results}

Following the discussion in the previous section, the regression model is specified as follows:

$$
I R S_{i, t}=\alpha+\beta B_{i, t}+\gamma I_{t}+\delta M_{t}+\varepsilon_{i, t}
$$

where $\mathrm{B}_{\mathrm{i}, \mathrm{t}}$ is a vector of bank-specific variables for bank $i$ and time $t$ such as overhead costs, liquidity ratio, capital ratio, bank size, NPL, MSD, and non-interest income; $\mathrm{I}_{\mathrm{t}}$ contains timevarying market and ownership structure variables, such as FLI and HHI; $\mathrm{M}_{t}$ is a vector of time-varying macroeconomic variables, such as QI, Inflation, Corporate tax rate and LRR.

In the banking sector analysis, not all firm characteristics are captured in the available data. Information on managerial risk aversion, revealed preferences, governance structure, cash flow characteristics and other relevant information may be difficult to measure. Ignoring the unobserved firm-level heterogeneity imposes the incorrect assumption of zero correlation between the observed variables and the unobserved effect. This leads to biased and inconsistent estimates (Wooldridge, 2002). Including fixed effects in a dynamic panel that most of the existing studies on spreads did, however, is also problematic. As first identified by Nickell (1981), the firm fixed effect is correlated with the lagged dependent variable. This introduces a bias which is substantial with shorter panels, if time-period is small (Wooldridge, 2002; Baltagi, 2005). The degree of inconsistency is an inverse function of the panel length (Nickell, 1981). Judson and Owen's (1999) simulations indicate that this bias can be quite large even for panels with 30 observations per unit.

To address this short panel bias, there are a number of choices. The first option is to use a traditional instrumental variables (IV) approach. If an appropriate IV is available, it can be used to instrument for the lagged dependent variable. However, in corporate finance, reliable instruments are difficult to find. Arellano and Bond (1991) suggest a generalized method of moments (GMM, or difference GMM) estimator. They first-difference the panel data and then use the endogenous (or predetermined) lagged variables' levels to instrument for the transformed lagged dependent variable. The lagged levels provide little information about the first differences when the underlying series are relatively stationary and, therefore, are weak instruments (Arellano and Bover, 1995; Blundell and Bond, 1998). The Arellano- 
Bover/Blundell-Bond GMM employs additional moment conditions based on the lagged variables' first differences (in addition to their levels) to increase the efficiency of the estimation.

Therefore, to increase the efficiency of the estimates as well as to capture some unobserved effects such mangers' revealed preferences, problems of corporate governance etc., the Arellano-Bover/Blundell-Bond GMM model has been applied in the analysis. Table 11 presents dynamic panel regression estimates on the determinants of interest rate spreads and margins for all banks for the period 1990-2008. It also presents estimates for the periods before 1999 and after 1999. Although liberalization started in the 1990s, the interest rate deregulations completed in 1999. Therefore, the period before 1999 represents partial liberalization and after 1999 represents post-liberalization.

Estimates for the whole period provide evidence for risk-based and market structure view and some evidence for macroeconomic view regarding the determinants of interest spreads and margins in Bangladesh. Estimates do not provide evidence for small financial system view. Lagged interest spreads and margins are found to be significant, indicating persistency in interest rate spreads and margins. In other words, persistency of spreads and margins capture unobserved characteristics, such as bank managements' revealed preferences, problems of corporate governance, insider operations etc., as well as it reflects existence of agency cost problem in the banking sector of Bangladesh.

Overhead cost and NPL are found to be positively and significantly associated with high interest spread for the whole sample period as well as for the post-liberalization period, but insignificantly associated with margin. Both the factors indicate inefficiency of the management for which the cost has to borne by the customers. For the partially liberalized period, capital ratio is found to be negatively associated with spreads. Since the partially liberalized period was dominated by SCBs, the low capital base of SCBs created some uncertainty on the profitability thereby contributed to high spreads. The coefficient of bank size is significant and negative to interest margin, indicating that bigger size significantly reduce banks' margin. If larger banks enjoy scale economies, it can lead them to operate with lower average costs. On the other hand, before 1999, bank size was significant and positive to spread indicating that larger banks have more market power which was conducive to higher spread.

Market share of deposits (MSD) is not found to be significant, lending no support to small financial system view to explaining high spreads or margins. Since MSD is not 
significant, expectation on more deposit mobilization with the reduction of NSD certificate rate may not be realistic as well as it may not help reduce spread.

Although financial liberalization has no significant effect on spread, it has positive and significant effect on interest margin. Herfindahl-Hirschman index (HHI) representing market concentration on loans has been included in the model. The HHI is found to be significant to spreads for all banks for the whole period and for the period before 1999, but insignificant for the post-liberalization period.

From macroeconomic point of view, quantum index (QI) of production is found to be positive and significant to spreads. The QI represents an index of industrial production which is relevant to investment behavior of firms. A positive association of QI with spread indicates that a higher industrial production increases the demand for investments leading to higher spreads. On the other hand, inflation is found to be positively associated with spread only for the liberalized period.

Liquidity reserve requirement (LRR), which is currently 20 percent, is found to be negative and significant to spread, but positive and significant to interest margin. Reserve requirements are a form of financial taxation on commercial banks, therefore, commercial banks respond to increases in reserve requirements by increasing the margin between deposit and lending rate. Therefore, it may act as a monetary policy instrument to reduce the spread.

The coefficients on bank discount rate and corporate tax rate have been found significant and negative to interest rate margin, but insignificant to spread. Currently bank discount rate is 5 percent and corporate tax rate is 42.5 percent. Particularly, tax rate is perceived to be high by bankers, which may contribute to lower margins.

\section{For PCBs:}

The determinants of interest rate spreads and margins are analyzed separately for PCBs. Table 12 presents estimates for all PCBs, new generation PCBs (those were established on or after 1999) and old PCBs (those were established before 1999). For all PCBs, lagged spreads and margins are found to be significant indicating persistency in spreads and margins. The coefficient of overhead cost is found to be positive and significant to spread for all PCBs and new PCBs, however, overhead cost is not significant for old PCBs.

The capital ratio is positive and significant to interest margins for all PCBs, particularly for new PCBs. This indicates that high margins contribute to high bank earnings, which are channeled into capital base of these banks. The bank size is negative and significant to interest margin, indicating that PCBs are operating at economies of scale. Herfindahl index is significant to spreads for old $\mathrm{PCBs}$, but it is significant to interest margin 
in case of all types of PCBs. Therefore, it may be concluded that high spreads and margins in PCBs, particularly the older and bigger PCBs are attributed to a certain degree of monopoly power. Financial liberalization seems to have widened the interest margins.

From macroeconomic aspects, while QI is positive, inflation and LRR are negative and significant to spreads and margins. While corporate income tax is positively and significantly associated, bank rate is negatively and significantly associated with interest margin.

\section{For SCBs:}

Overhead cost, bank size and non-interest income are found to be significant to spreads in SCBs. These factors, in other words, indicate inefficiency of the management of these banks. Such inefficiencies are attributed to several factors: (i) government intervention in loan disbursement as well as in management; (ii) highest number of branches as well as employees, which lead to high administrative costs; and (iii) poor service quality of these banks. Moreover, IRS in SCBs is partly influenced by macroeconomic environment as inflation and LRR are found to be positive and significant.

Therefore, to make a competitive environment in the banking sector of Bangladesh, there is no alternative other than making SCBs more efficient. Strong political will is necessary for this purpose. Recently, the government has made SCBs limited companies with independent/privately recruited management. However, as the government owns 100 percent share of these banks, it is very unlikely that the management could work without any intervention of the government. Hence, making these banks competitive and efficient is still a far reaching objective.

\section{Conclusion}

This study has attempted to explain why interest spreads and margins are persistently high in Bangladesh. Like in many developing countries, there is no simple explanation for the generally high level of bank spreads and margins in Bangladesh. High operating costs and NPL raise spreads in Bangladesh. Also, market power, liquidity reserve requirements act as important determinants of a higher spread. From macroeconomic point of view, quantum index of industrial production has been found to be significant to spreads. Spreads and margins are significantly persistent, indicating to some problems of corporate governance in the banking sector of Bangladesh. These findings suggest that financial reforms in Bangladesh have not contributed much to make the banking sector competitive and efficient.

Moreover, this study finds that any change in spreads is mainly driven by a change in 
deposit rates, keeping lending rates almost unchanged. As spreads widen due to high lending rate or low deposit rate, the cost of using the financial system becomes prohibitive to an increasing number of potential borrowers. In this sense, imposing ceiling on spreads instead of lending rates, which is currently in place, could be more effective in the short run.

Thus, the factors that appear to propel high spreads and margins are distortions in the loans market, institutional impediments and the policy environment. All these factors together imply that banking sector in Bangladesh is not efficient and competitive despite a certain degree of financial reforms. A certain degree of monopoly power exists in the system. Therefore, it is the combination of several factors that is the cause of concern for Bangladesh. Bangladesh Bank should strive for effective monetary policy instruments that can contribute to making interest rates responsive to market developments. Corporate governance in the banking sector must be improved, particularly in the case of state-owned banks. Making state-owned banks more efficient could be considered as one of the ways to make the banking sector more vibrant and competitive in the long run. Moreover, institutional development such as capital market and bond market development as well as capacity building in supervisory activities of Bangladesh Bank could be of useful in making the sector more competitive and efficient.

\section{Acknowledgements:}

The author is grateful to K.A.S Murshid for funding this study through BIDS-PRP project, and his critical review of an earlier version of the paper. Thanks to Maruf Ahmed for providing excellent research assistance. The author is also thankful to Salehuddin Ahmed, Qazi Kholiquzzaman, Muhammad A. (Rumee) Ali and Mohammad Yunus for their helpful comments in a seminar on the paper.

\section{References:}

Agu, C.C., (1992). "Analysis of the Determinants of the Nigerian Banking System's Profits and Profitability Performance", Savings and Development, 16(4), 353-369.

Ahmed, S. and M. E. Islam (2006). Interest Rate Spread in Bangladesh: An Analytical Review, Policy Note Series PN 0701, Policy Analysis Unit, Bangladesh Bank, Dhaka.

Angbazo, L., (1997). “Commercial Bank Net Interest Margins, Default Risk, Interest-Rate Risk, and Off-Balance Sheet Banking", Journal of Banking and Finance, 21, 55-87.

Arellano, Manuel and Olympia Bover (1995): "Another look at the instrumental variable estimation of error-components models" Journal of Econometrics, Vol. 68, Issue 1, 29-51. 
Aryeetey, E., H. Hettige, M. Nissanke and W. Steel (1997). "Financial Market Fragmentation and Reforms in Ghana, Malawi, Nigeria, and Tanzania", World Bank Economic Review, 11(2), 195-218.

Baltagi, Badi H. (2005). Econometric Analysis of Panel Data, John Wiley and Sons, West Sussex.

Bangladesh Bank (2006). Financial Sector Review, 1(1), May.

Bangladesh Bank (2007). Financial Sector Review, 3(1), December.

Bangladesh Bank (2007). Monetary Policy Review, 3(1), October.

Bangladesh Bank (2008). Annual Report.

Bangladesh Bank (2007/2008). Bangladesh Bank Quarterly.

Bangladesh Bank (2008). Economic Trends.

Bangladesh Bank (2008). Scheduled Bank Statistics.

Barajas, A., R. Steiner, and N. Salazar (1999). "Interest Spreads in Banking in Colombia, 1974-96", IMF Staff Papers, 46(2).

Barajas, A., R. Steiner, and N. Salazar (2000). "The Impact of Liberalization and Foreign Investment in Colombia's Financial Sector", Journal of Development Economics, 63(1), 157196.

Beck, Thorsten and Heiko Hesse, (2009). "Why are interest spreads so high in Uganda?", Journal of Development Economics, Vol. 88, 192-204

Blundell, Richard and Stephen Bond (1998). "Initial Conditions and Moment Restrictions in Dynamic Panel Data Models", Journal of Econometrics 87, 115-143.

Brock, P. L. and L. Rojas-Suarez (2000). "Understanding the Behavior of Bank Spreads in Latin America", Journal of Development Economics, 63, 113-134.

Brock, Philip L. and Liliana Rojas Suarez (2000). "Understanding the behavior of bank spreads in Latin America”, Journal of Development Economics, Vol. 63, 113-134.

Chirwa, E. W. and M. Mlachila (2004). "Financial Reforms and Interest Rate Spreads in the Commercial Banking System in Malawi”, IMF Staff Papers, 51(1).

Crowley, J. (2007). "Interest Rate Spreads in English-Speaking African Countries", IMF Working Paper WP/07/101, International Monetary Fund, Washington D.C.

Demirgüc-Kunt, A. and H. Huizinga (1999). "Determinants of Commercial Bank Interest Margins and Profitability: Some International Evidence". World Bank Economic Review, 13, 379-408.

Freixas, X. and J. C. Rochet (1997). Microeconomics of Banking, MIT Press, Cambridge, Massachusetts.

Fry, M.J. (1995). Money, Interest, and Banking in Economic Development, Second Edition, Baltimore and London: Johns Hopkins University Press.

Greene, W. H. (2000). Econometric Analysis, Fourth Edition, Prentice Hall, New Jersey.

Hanson, J.A. and R.R. Rocha (1986). "High Interest Rates, Spreads and the Costs of Intermediation: Two Studies", Industry and Finance Series, 18, World Bank, Washington D.C. 
Judson, Ruth A. and Ann L. Owen, (1999). "Estimating Dynamic Panel Data Models: A Guide for Macroeconomists," Economic Letters 65, 9-15.

Morris, F. et. al. (1990). Latin America's Banking Systems in the 1980s: A Cross Country Comparison, World Bank, Washington D.C.

Mujeri, M. K. and M.E. Islam (2008). Rationalizing Interest Rate Spread in the banking Sector: Some Policy Suggestions, Policy Paper No. PP 0804, Policy Analysis Unit, Bangladesh Bank, Dhaka.

Nickell, Stephen (1981). "Biases in Dynamic Models with Fixed Effects", Econometrica 49, 1417-1426.

Ramful, P. (2001). The Determinants of Interest Rate Spread: Empirical Evidence on the Mauritian Banking Sector, Research Department, Bank of Mauritius, May, 1-20

Randall, R. (1998). "Interest Rate Spreads in the Eastern Caribbean", IMF Working Paper WP/98/59, International Monetary Fund, Washington D.C.

Santomero, A. M., (1984). "Modeling the Banking Firm: A Survey", Journal of Money Credit and Banking, 16(4), 576-602.

Saundars, A. and L. Schumacher (2000): "The determinants of bank interest rate margins: an international study", Journal of International Money and Finance, 19, 813-832.

Shaffer, S. (1989). "Competition in the US Banking Industry", Economic Letters, 29(4), 321323.

Shaffer, S. (1993). “A Test of Competition in Canadian Banking”, Journal of Money Credit and Banking, 25, 49-61.

Smirlock, M. (1985). "Evidence on the (Non) Relationship between the Concentration Ratio and Profitability in Banking", Journal of Money Credit and Banking, 17(1), 69-83.

Wooldridge, Jeffrey M. (2002). Econometric Analysis of Cross Sectional and Panel Data, The MIT Press, Cambridge. 
Table 1. An international comparison of the determinants of interest rate spreads and margins

\begin{tabular}{|c|c|c|c|}
\hline References & Country/ Sample period & Methodology & Determinants of spreads/margins \\
\hline \multicolumn{4}{|c|}{ A. African countries } \\
\hline $\begin{array}{l}\text { Beck and Hesse } \\
(2009)\end{array}$ & $\begin{array}{l}\text { Uganda. } 1999-2005 . \\
\text { Average spread: } 18 \% .\end{array}$ & $\begin{array}{l}\text { Pooled OLS; } \\
\text { Median Least } \\
\text { Square; Fixed } \\
\text { Effect }\end{array}$ & $\begin{array}{l}\text { Small market, high operating cost, } \\
\text { high inflation, high T-bill rate, } \\
\text { exchange rate appreciation }\end{array}$ \\
\hline Crowley (2007) & $\begin{array}{l}18 \text { African countries } \\
\text { (Botswana, Ethiopia, Gambia, } \\
\text { Ghana, Kenya, Lesotho, } \\
\text { Malawi, } \\
\text { Mauritius, Mozambique, } \\
\text { Namibia, Nigeria, Rwanda, } \\
\text { Sierra Leone, Swaziland, } \\
\text { Tanzania, Uganda, Zambia, and } \\
\text { Zimbabwe). 1975-2004. } \\
\text { Average spread: } 7 \%\end{array}$ & $\begin{array}{l}\text { Cross-section } \\
\text { OLS }\end{array}$ & $\begin{array}{l}\text { Low inflation, greater number of } \\
\text { banks, greater public ownership of } \\
\text { banks, poor governance, higher } \\
\text { reserve ratio }\end{array}$ \\
\hline $\begin{array}{l}\text { Chirwa and } \\
\text { Mlachila (2004) }\end{array}$ & $\begin{array}{l}\text { Malawi. 1989-99. } \\
\text { Average spread: } 16.75 \% *\end{array}$ & $\begin{array}{l}\text { Fixed effect, } \\
\text { Random effect } \\
\text { panel } \\
\text { regression }\end{array}$ & $\begin{array}{l}\text { Monopoly power, reserve } \\
\text { requirements, discount rate, inflation }\end{array}$ \\
\hline \multicolumn{4}{|c|}{ B. Eastern Caribbean countries. } \\
\hline Randall (1998) & $\begin{array}{l}\text { Eastern Caribbean countries } \\
\text { (Antigua and Barbuda, } \\
\text { Dominica, Grenada, St. Kitts } \\
\text { and Nevis, St. Lucia, and St. } \\
\text { Vincent and the Grenadines). } \\
\text { 1991-96. } \\
\text { Average spread: } 7.3 \%\end{array}$ & $\begin{array}{l}\text { Two-stage } \\
\text { least square }\end{array}$ & Operating cost, loan loss provision \\
\hline \multicolumn{4}{|c|}{ C. Latin American countries } \\
\hline $\begin{array}{l}\text { Brock and Rojas- } \\
\text { Suarez (2000) }\end{array}$ & $\begin{array}{l}\text { Latin America. 1991-1995. } \\
\text { Argentina (12.9\%), Bolivia } \\
(7.1 \%) \text {, Colombia }(21 \%) \text {, Chile } \\
(11.6 \%), \text { Peru }(20 \%), \text { Mexico } \\
(7.7 \%) .\end{array}$ & $\begin{array}{l}\text { Two-step } \\
\text { regression }\end{array}$ & $\begin{array}{l}\text { Capital ratio, cost ratio, liquidity } \\
\text { ratio, interest rate volatility, inflation }\end{array}$ \\
\hline $\begin{array}{l}\text { Barajas et al. } \\
\text { (1999) }\end{array}$ & $\begin{array}{l}\text { Colombia. 1974-1996. } \\
\text { Average Spread: 16-32\% } \\
(1974-1988) ; 25-19 \%(1988- \\
1996)^{*}\end{array}$ & $\begin{array}{l}\text { Two-stage } \\
\text { least squares }\end{array}$ & $\begin{array}{l}\text { Operating cost, financial taxation, } \\
\text { loan quality }\end{array}$ \\
\hline \multicolumn{4}{|c|}{ D. OECD countries } \\
\hline $\begin{array}{l}\text { Saunders and } \\
\text { Schumacher } \\
(2000)\end{array}$ & $\begin{array}{l}7 \text { OECD countries (Germany, } \\
\text { Spain, France, U.K., Italy, } \\
\text { USA, Switzerland). }\end{array}$ & $\begin{array}{l}\text { Two-step } \\
\text { regression }\end{array}$ & $\begin{array}{l}\text { Capital ratio, monopoly power, } \\
\text { volatility of interest rates }\end{array}$ \\
\hline Angbazo (1997) & US. 1989-1993 & & $\begin{array}{l}\text { De fault risk, opportunity cost of non- } \\
\text { interest bearing reserves, leverage, } \\
\text { management efficiency }\end{array}$ \\
\hline \multicolumn{4}{|c|}{ E. South Asian Countries } \\
\hline $\begin{array}{l}\text { Mujeri and Islam } \\
(2008)\end{array}$ & Bangladesh & $\begin{array}{l}\text { Summary } \\
\text { Statistics }\end{array}$ & Not available \\
\hline $\begin{array}{l}\text { Ahmed and Islam } \\
\text { (2006) }\end{array}$ & Bangladesh & $\begin{array}{l}\text { Summary } \\
\text { statistics }\end{array}$ & $\begin{array}{l}\text { Limited competition, overstaffing, } \\
\text { high administrative costs, the burden }\end{array}$ \\
\hline
\end{tabular}




\begin{tabular}{|l|l|l|l|}
\hline \multicolumn{2}{|l|}{} & & $\begin{array}{l}\text { of NPLs, and above all, congruence } \\
\text { between monetary and fiscal policy } \\
\text { stances. }\end{array}$ \\
\hline Khawaja (2007) & Pakistan. 1998-2005. & $\begin{array}{l}\text { Fixed effect } \\
\text { model }\end{array}$ & Inelasticity of deposit, Liquidity, NPL \\
\hline F. Cross-country Analysis & $\begin{array}{l}\text { Cross- } \\
\text { sectional OLS }\end{array}$ & $\begin{array}{l}\text { Bank size, Real T-bill rate, Liquidity } \\
\text { ratio, Concentration, Inflation, GDP } \\
\text { growth, institutional deficiencies, } \\
\text { overhead cost }\end{array}$ \\
\hline $\begin{array}{l}\text { Beck and Hesse } \\
(2009)\end{array}$ & $\begin{array}{l}\text { Cross-country. 86 countries; } \\
\text { 2000-2004; } \\
\text { Average spread: 5\% }\end{array}$ & $\begin{array}{l}\text { Ratio of equity to lagged total asset, } \\
\text { ratio of loans to total assets, foreign } \\
\text { ownership, bank size, overhead cost, } \\
\text { inflation rate, short-term market } \\
\text { interest rate }\end{array}$ \\
\hline $\begin{array}{l}\text { Demirgüc-Kunt } \\
\text { and Huizinga } \\
(1999)\end{array}$ & Cross-country (80). 1988-1995 & $\begin{array}{l}\text { Cross- } \\
\text { sectional OLS }\end{array}$ \\
\hline
\end{tabular}

*Estimation of spread depends on a particular definition.

Table 2: Scenario of the Banking sector in Bangladesh (as of March, 2009)

\begin{tabular}{|c|c|c|c|c|c|c|}
\hline \multirow[t]{2}{*}{ Bank type } & \multirow[t]{2}{*}{ Number } & \multicolumn{3}{|c|}{ Number of branches } & \multirow{2}{*}{$\begin{array}{l}\text { Percentage of } \\
\text { total asset }\end{array}$} & \multirow{2}{*}{$\begin{array}{l}\text { Percentage of } \\
\text { total deposit }\end{array}$} \\
\hline & & Rural & Urban & Total & & \\
\hline $\begin{array}{l}\text { State owned } \\
\text { (SOBs) }\end{array}$ & 4 & $\begin{array}{l}2146 \\
(63.4 \%)\end{array}$ & $\begin{array}{l}1240 \\
(36.6 \%)\end{array}$ & $\begin{array}{l}3386 \\
(100 \%)\end{array}$ & 30.66 & 48.07 \\
\hline $\begin{array}{l}\text { Private } \\
\text { commercial } \\
\text { banks (PCBs) }\end{array}$ & 30 & $\begin{array}{l}634 \\
(30.3 \%)\end{array}$ & $\begin{array}{l}1461 \\
(69.7 \%)\end{array}$ & $\begin{array}{l}2095 \\
(100 \%)\end{array}$ & 53.71 & 29.71 \\
\hline $\begin{array}{l}\text { Specialized } \\
\text { banks (SBs) }\end{array}$ & 5 & $\begin{array}{l}1206 \\
(88.5 \%)\end{array}$ & $\begin{array}{l}157 \\
(11.5 \%)\end{array}$ & $\begin{array}{l}1363 \\
(100 \%)\end{array}$ & 6.08 & 8.31 \\
\hline $\begin{array}{l}\text { Foreign Banks } \\
\text { (FCBs) }\end{array}$ & 9 & 0 & $\begin{array}{l}56 \\
(100 \%) \\
\end{array}$ & $\begin{array}{l}56 \\
(100 \%) \\
\end{array}$ & 9.55 & 13.91 \\
\hline Total & 48 & $\begin{array}{l}3986 \\
(57.8 \%)\end{array}$ & $\begin{array}{l}2914 \\
(42.2 \%) \\
\end{array}$ & $\begin{array}{l}6900 \\
(100 \%)\end{array}$ & 100.00 & 100.00 \\
\hline
\end{tabular}

Source: Bangladesh Bank

Table 3: Financial intermediation in Bangladesh

\begin{tabular}{|c|c|c|c|c|c|c|}
\hline $\begin{array}{l}\text { Period } \\
\text { average }\end{array}$ & $\begin{array}{l}\text { Interest } \\
\text { rate } \\
\text { (lending) }\end{array}$ & $\begin{array}{l}\text { Credit to } \\
\text { private } \\
\text { sector } \\
\text { (\% of } \\
\text { GDP) }\end{array}$ & $\begin{array}{l}\text { Total } \\
\text { deposits } \\
\text { (\% of } \\
\text { GDP) }\end{array}$ & $\begin{array}{l}\text { Broad } \\
\text { money } \\
(\% \text { of } \\
\text { GDP }\end{array}$ & $\begin{array}{l}\text { Gross fixed capital } \\
\text { formation (gross } \\
\text { investment) (\%GDP) }\end{array}$ & $\begin{array}{c}\text { GDP per } \\
\text { capita at } \\
\text { current US } \\
\text { dollar }\end{array}$ \\
\hline $\begin{array}{r}1976- \\
1980\end{array}$ & 11.09 & 6.59 & 14.86 & 19.03 & 10.44 & 160.0 \\
\hline $\begin{array}{r}1981- \\
1985\end{array}$ & 13.68 & 13.67 & 20.23 & 24.54 & 10.51 & 192.0 \\
\hline $\begin{array}{r}1986- \\
1990\end{array}$ & 14.71 & 19.08 & 24.75 & 28.67 & 13.87 & 242.0 \\
\hline $\begin{array}{r}1991- \\
1995\end{array}$ & 13.90 & 16.58 & 23.07 & 26.68 & 17.93 & 283.0 \\
\hline $\begin{array}{r}1996- \\
2000\end{array}$ & 13.83 & 23.17 & 26.7 & 31.01 & 21.51 & 353.0 \\
\hline $\begin{array}{r}2001- \\
2005\end{array}$ & 12.33 & 28.83 & 35.08 & 40.02 & 22.63 & 395.0 \\
\hline $\begin{array}{r}2006- \\
2008\end{array}$ & 13.40 & 34.5 & 45.0 & 45.0 & 24.4 & 565.5 \\
\hline
\end{tabular}

Sources: Bangladesh Bank and Ministry of Finance. 
Table 4. Interest rate structure across banks in Bangladesh (yearly average)

\begin{tabular}{|c|c|c|c|c|c|c|c|c|c|c|}
\hline Year & $\begin{array}{l}\text { Savings } \\
\text { rate }\end{array}$ & $\begin{array}{l}\text { Fixed } \\
\text { deposit } \\
\text { rate }\end{array}$ & $\begin{array}{l}\text { Interest } \\
\text { on } \\
\text { agri } \\
\text { loan }\end{array}$ & $\begin{array}{l}\text { Interest } \\
\text { on } \\
\text { large } \\
\text { term } \\
\text { loan }\end{array}$ & $\begin{array}{l}\text { Interest } \\
\text { on } \\
\text { small } \\
\text { term } \\
\text { loan }\end{array}$ & $\begin{array}{l}\text { Interest } \\
\text { on } \\
\text { working } \\
\text { capital }\end{array}$ & $\begin{array}{l}\text { Interest } \\
\text { on } \\
\text { exports }\end{array}$ & $\begin{array}{l}\text { Interest } \\
\text { on } \\
\text { trade } \\
\text { financing }\end{array}$ & $\begin{array}{l}\text { Interest } \\
\text { on } \\
\text { house } \\
\text { financing }\end{array}$ & $\begin{array}{l}\text { Interest } \\
\text { on } \\
\text { consume } \\
\text { rs loan }\end{array}$ \\
\hline 2004 & 5.50 & 7.60 & 9.37 & 11.50 & 10.88 & 11.88 & 7 & 12.49 & 10.02 & 7.29 \\
\hline 2005 & 5.56 & 7.91 & 9.41 & 11.61 & 10.97 & 12.01 & 7 & 12.59 & 10.15 & 8.81 \\
\hline 2006 & 5.99 & 9.59 & 9.92 & 13.19 & 12.08 & 13.59 & 7 & 14.30 & 12.95 & 13.66 \\
\hline 2007 & 5.99 & 9.82 & 9.93 & 12.90 & 11.98 & 13.75 & 7 & 14.41 & 12.98 & 14.16 \\
\hline 2008 & 5.95 & 10.98 & 10.41 & 12.48 & 12.10 & 13.07 & 7 & 14.07 & 12.85 & 14.56 \\
\hline
\end{tabular}

Table 5: Correlation of spread with loan and deposit rate

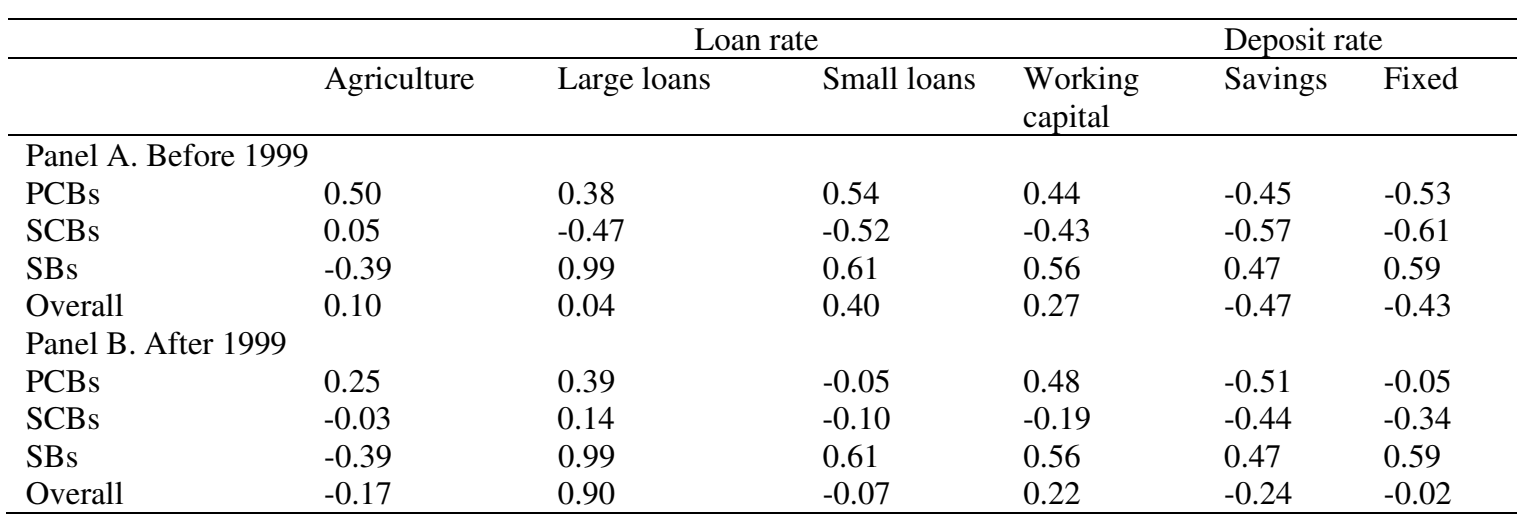

Table 6: Coefficients of variations in spreads for PCBs and SCBs over the years

\begin{tabular}{cccc|cccc}
\hline Year & PCBs & SCBs & Overall & Year & PCBs & SCBs & Overall \\
\hline 1993 & 0.10 & 0.04 & 0.09 & 2001 & 0.30 & 0.08 & 0.28 \\
1994 & 0.15 & 0.05 & 0.13 & 2002 & 0.28 & 0.22 & 0.27 \\
1995 & 0.16 & 0.05 & 0.14 & 2003 & 0.39 & 0.13 & 0.36 \\
1996 & 0.13 & 0.03 & 0.11 & 2004 & 0.37 & 0.11 & 0.34 \\
1997 & 0.13 & 0.25 & 0.16 & 2005 & 0.42 & 0.12 & 0.39 \\
1998 & 0.22 & 0.03 & 0.18 & 2006 & 0.42 & 0.13 & 0.39 \\
1999 & 0.21 & 0.14 & 0.19 & 2007 & 0.32 & 0.15 & 0.31 \\
2000 & 0.24 & 0.09 & 1.41 & 2008 & 1.01 & 0.29 & 0.91 \\
\hline
\end{tabular}

Source: Author's estimate

Table 7: Granger-causality test between spread and interest rates, 1990-2008

Panel A. Causality between IRS and Deposit rate

\begin{tabular}{lccc}
\hline Null Hypothesis: & Obs & F-Statistic & Probability \\
\hline ID does not Granger Cause IRS & 13 & 0.37 & 0.69 \\
IRS does not Granger Cause ID & & 6.74 & 0.02 \\
Panel B. Causality between IRS and lending rate & & & \\
\hline Null Hypothesis: & Obs & F-Statistic & Probability \\
\hline IL does not Granger Cause IRS & 13 & 0.34 & 0.72 \\
IRS does not Granger Cause IL & & 0.23 & 0.79 \\
\hline
\end{tabular}


Table 8: Pair-wise Granger Causality tests: 1990-2008

Panel A: Causality between interest bearing deposits and deposit interest rates

\begin{tabular}{lccc}
\hline Null Hypothesis: & Obs & F-Statistic & Probability \\
\hline INTDEPOS does not Granger Cause ID & 17 & 1.28 & 0.31 \\
ID does not Granger Cause INTDEPOS & & 0.17 & 0.84 \\
Panel B: Causality between total loan and lending rates & & & \\
\hline Null Hypothesis: & Obs & F-Statistic & Probability \\
\hline TOTLOAN does not Granger Cause IL & 17 & 0.51 & 0.61 \\
IL does not Granger Cause TOTLOAN & & 1.13 & 0.35 \\
\hline
\end{tabular}

Table 9: Summary statistics of key variables

\begin{tabular}{|c|c|c|c|c|c|c|c|c|}
\hline stats & $\begin{array}{l}\text { Interest } \\
\text { spread }\end{array}$ & $\begin{array}{l}\text { Overhead } \\
\text { cost as \% } \\
\text { of total } \\
\text { asset }\end{array}$ & \begin{tabular}{l}
\multicolumn{2}{l}{ Capital } \\
ratio as \\
$\%$ \\
total \\
asset
\end{tabular} & $\begin{array}{ll}\text { NPL } & \text { as } \\
\% & \text { of } \\
\text { total } & \\
\text { loan } & \end{array}$ & $\begin{array}{l}\text { Liquidity } \\
\text { Reserve } \\
\text { Ratio (\%) }\end{array}$ & $\begin{array}{l}\text { Non- } \\
\text { interest } \\
\text { income } \\
\text { as \% of } \\
\text { interest } \\
\text { income }\end{array}$ & MSD & $\begin{array}{l}\text { Loan } \\
\text { Share }\end{array}$ \\
\hline All & 5.18 & 0.05 & 0.20 & 9.00 & 19.57 & 26 & .02 & 0.02 \\
\hline \multirow[t]{2}{*}{ banks } & 1.70 & 0.48 & 1.30 & 0.10 & 1.73 & 0.17 & 0.03 & 0.03 \\
\hline & 0.33 & 9.08 & 6.39 & 1.23 & 0.09 & 0.67 & 1.82 & 0.45 \\
\hline \multicolumn{9}{|l|}{ SCBs } \\
\hline mean & 5.83 & 4.00 & 0.14 & 16 & 22.21 & 23 & 0.09 & 0.10 \\
\hline $\mathrm{sd}$ & 0.91 & 0.02 & 0.12 & 0.12 & 0.60 & 0.12 & 0.06 & 0.05 \\
\hline $\mathrm{cv}$ & 0.16 & 0.66 & 0.86 & 0.75 & 0.03 & 0.50 & 0.69 & 0.45 \\
\hline \multicolumn{9}{|c|}{ SCBs (year>1999) } \\
\hline mean & 5.45 & 2.00 & 0.04 & 21 & 22.45 & 25 & 0.08 & 0.10 \\
\hline sd & 0.81 & 0.01 & 0.03 & 0.11 & 0.61 & 0.09 & 0.05 & 0.05 \\
\hline $\mathrm{cv}$ & 0.15 & 0.34 & 0.89 & 0.55 & 0.03 & 0.34 & 0.66 & 0.45 \\
\hline \multicolumn{9}{|l|}{ PCB } \\
\hline mean & 5.01 & 6.00 & 0.22 & 7 & 20.01 & 24 & 0.01 & 0.015 \\
\hline sd & 1.82 & 0.58 & 1.57 & 0.10 & 1.13 & 0.13 & 0.01 & 0.01 \\
\hline $\mathrm{cv}$ & 0.36 & 9.18 & 7.05 & 1.36 & 0.06 & 0.55 & 0.87 & 0.79 \\
\hline \multicolumn{9}{|c|}{ PCBs NEW } \\
\hline mean & 3.75 & 14.0 & 0.42 & 3 & 19.48 & 20 & 0.01 & 0.017 \\
\hline sd & 2.00 & 1.14 & 3.08 & 0.03 & 1.35 & 0.11 & 0.00 & 0.01 \\
\hline $\mathrm{cv}$ & 0.53 & 8.34 & 7.35 & 0.85 & 0.07 & 0.54 & 0.83 & 0.71 \\
\hline \multicolumn{9}{|c|}{ PCBs OLD } \\
\hline mean & 5.42 & 4.0 & 0.16 & 8 & 20.12 & 25 & 0.01 & 0.015 \\
\hline sd & 1.56 & 0.02 & 0.16 & 0.10 & 1.07 & 0.14 & 0.01 & 0.01 \\
\hline $\mathrm{cv}$ & 0.29 & 0.62 & 1.01 & 1.31 & 0.05 & 0.55 & 0.81 & 0.77 \\
\hline \multicolumn{9}{|c|}{ PCBs (YEAR>1999) } \\
\hline mean & 4.62 & 7.0 & 0.21 & 7 & 20.25 & 21 & 0.01 & 1.66 \\
\hline sd & 1.88 & 0.71 & 1.92 & 0.10 & 1.09 & 0.09 & 0.01 & 1.29 \\
\hline $\mathrm{cV}$ & 0.41 & 10.40 & 9.33 & 1.38 & 0.05 & 0.43 & 0.82 & 0.77 \\
\hline
\end{tabular}


Table 10. Pair-wise correlation between bank-specific variables

\begin{tabular}{|c|c|c|c|c|c|c|c|c|c|c|c|}
\hline & $\begin{array}{l}\text { Interest } \\
\text { spread }\end{array}$ & $\begin{array}{l}\text { Over } \\
\text { head }\end{array}$ & $\begin{array}{l}\text { Capital } \\
\text { Ratio } \\
\end{array}$ & NPL & $\begin{array}{l}\text { Bank } \\
\text { size }\end{array}$ & $\begin{array}{l}\text { Non } \\
\text { interest } \\
\text { income }\end{array}$ & MSD & $\mathrm{HHI}$ & QI & Inflation & LRR \\
\hline \multicolumn{12}{|l|}{$\begin{array}{l}\text { Interest } \\
\text { spread }\end{array}$} \\
\hline Overhead & $-0.12 *$ & & & & & & & & & & \\
\hline Capital ratio & $-0.11 *$ & $0.99 *$ & & & & & & & & & \\
\hline NPL & $0.16^{*}$ & $-0.15^{*}$ & $0.12 *$ & & & & & & & & \\
\hline Bank size & 0.05 & $-0.21^{*}$ & $-0.24 *$ & $0.19 *$ & & & & & & & \\
\hline $\begin{array}{l}\text { Non-interest } \\
\text { income }\end{array}$ & $0.24 *$ & 0.001 & 0.03 & 0.01 & $-0.15 *$ & & & & & & \\
\hline MSD & $0.15 *$ & -0.01 & -0.02 & $0.30 *$ & $0.57 *$ & 0.01 & & & & & \\
\hline HHI & $0.16^{*}$ & -0.01 & -0.002 & $0.21 *$ & $0.45 *$ & -0.05 & $0.86^{*}$ & & & & \\
\hline QI & -0.08 & -0.01 & -0.01 & 0.05 & 0.06 & 0.03 & $-0.14 *$ & $-0.20 *$ & & & \\
\hline Inflation & $-0.23 *$ & -0.01 & -0.01 & -0.05 & $0.23 *$ & -0.001 & -0.03 & $-0.09 *$ & $0.15^{*}$ & & \\
\hline LRR & -0.06 & 0.003 & -0.03 & $0.20^{*}$ & $0.88^{*}$ & -0.08 & $0.56^{*}$ & $0.44 *$ & $\begin{array}{l}0.05 \\
-\end{array}$ & $0.25 *$ & \\
\hline Tax & $-0.12 *$ & 0.01 & -0.002 & 0.03 & 0.02 & $-0.13^{*}$ & -0.03 & 0.02 & $0.15 *$ & $-0.23 *$ & 0.05 \\
\hline
\end{tabular}

* Significant at 5 percent level. 
Table 11: Determinants of interest spreads and margins for all banks

\begin{tabular}{|c|c|c|c|c|c|c|}
\hline & \multicolumn{3}{|c|}{ Interest Spread } & \multicolumn{3}{|c|}{ Interest margin } \\
\hline & & $\begin{array}{c}\text { All banks } \\
\text { (before } \\
1999)\end{array}$ & $\begin{array}{c}\text { All banks } \\
\text { (after } \\
1999)\end{array}$ & & $\begin{array}{c}\text { All banks } \\
\text { (before 1999) }\end{array}$ & $\begin{array}{c}\text { All banks (after } \\
1999)\end{array}$ \\
\hline & All Banks & & & All Banks & & \\
\hline Lagged & 0.42 & $0.33(0.09)^{*}$ & 0.36 & 0.63 & & \\
\hline interest spread & $\begin{array}{c}(0.06) * * * \\
15.92\end{array}$ & $* *$ & $\begin{array}{c}(0.08)^{* * *} \\
20.81\end{array}$ & $(0.03)^{* * *}$ & $0.45(0.04)^{* * *}$ & $0.54(0.04)^{* * *}$ \\
\hline Overhead & $(6.63) * * *$ & $3.98(6.59)$ & $(9.12)^{* * *}$ & $0.23(0.57)$ & $-0.29(0.59)$ & $-0.25(0.65)$ \\
\hline Capital ratio & $\begin{array}{c}-1.27 \\
(1.05) \\
2.18\end{array}$ & $\begin{array}{c}-1.90 \\
(0.73)^{* * *}\end{array}$ & $\begin{array}{c}-1.36 \\
(1.87) \\
3.00\end{array}$ & $0.36(0.08)^{* *}$ & $0.07(0.05)$ & $0.20(0.10)^{* *}$ \\
\hline NPL & $(1.19)^{*}$ & $\begin{array}{c}-1.80(1.21) \\
2.39\end{array}$ & $\begin{array}{c}(1.60)^{* * *} \\
1.38\end{array}$ & $\begin{array}{r}-0.04(0.09) \\
-0.38\end{array}$ & $0.19(0.11)^{*}$ & $0.00(0.11)$ \\
\hline Bank size & $0.77(0.71)$ & $(1.01)^{* * *}$ & $(0.96)$ & $(0.05)^{* * *}$ & $-0.62(0.06)^{* * *}$ & $-0.40(0.06)^{* * *}$ \\
\hline $\begin{array}{l}\text { Non-interest } \\
\text { income }\end{array}$ & $0.22(0.85)$ & $-0.36(0.69)$ & $\begin{array}{l}0.20 \\
(1.32) \\
-1.54\end{array}$ & $0.13(0.07)^{*}$ & $0.00(0.04)$ & $0.07(0.11)$ \\
\hline MSD & $-0.76(2.99)$ & $2.51(2.83)$ & (4.02) & $0.14(0.30)$ & $0.27(0.22)$ & $-0.24(0.39)$ \\
\hline & $0.00(0.00)$ & -0.01 & 0.00 & & & \\
\hline HHI & $* * *$ & $(0.00)^{* * *}$ & $(0.00)$ & $0.00(0.00)$ & $0.00(0.00)$ & $0.00(0.00)$ \\
\hline QI & $\begin{array}{c}0.00(0.00) \\
* * *\end{array}$ & $\begin{array}{c}-0.01 \\
(0.01)^{* *} \\
0.07\end{array}$ & $\begin{array}{c}0.00 \\
(0.00)^{* * *} \\
-0.05\end{array}$ & $0.00(0.00)$ & $0.00(0.00)^{*}$ & $0.00(0.00)$ \\
\hline Inflation & $-0.02(0.02)$ & $(0.02)^{* * *}$ & $(0.03)$ & $0.00(0.00)$ & $0.00(0.00)$ & $0.00(0.00)$ \\
\hline FLI & $\begin{array}{c}-0.33(0.27) \\
-\end{array}$ & $-0.08(0.23)$ & & $0.20(0.03)^{* * *}$ & & \\
\hline LRR & $\begin{array}{l}0.73(0.26) \\
* * *\end{array}$ & $\begin{array}{c}0.11 \\
(0.27) \\
134(064) *\end{array}$ & $\begin{array}{c}-0.97 \\
(0.35)^{* * *}\end{array}$ & $\begin{array}{r}0.13 \\
(0.01)^{* * *} \\
-001\end{array}$ & $\begin{array}{r}0.23 \\
(0.02)^{* * *}\end{array}$ & $0.13(0.02)^{* * *}$ \\
\hline Bank rate & $-0.02(0.03)$ & $\begin{array}{c}1.34(0.04) \\
* *\end{array}$ & $0.03(0.04)$ & $(0.00)^{* * *}$ & $0.02(0.04)$ & $-0.01(0.00)^{* * *}$ \\
\hline Tax & $\begin{array}{l}-2.52(2.33) \\
8.70(3.61)\end{array}$ & $\begin{array}{c}-5.11(7.89) \\
-19.76\end{array}$ & $\begin{array}{c}- \\
3.66(5.04) \\
7.28\end{array}$ & $\begin{array}{r}-0.88 \\
(0.22)^{* * *} \\
1.61\end{array}$ & $0.64(0.53)$ & $0.21(0.31)$ \\
\hline Constant & $* * *$ & $(6.30) * * *$ & $(4.88)$ & $(0.34) * * *$ & $0.76(0.78)$ & $1.31(0.41)^{* * *}$ \\
\hline $\mathrm{N}$ & 300 & 80 & 220 & 332 & 72 & 260 \\
\hline Wald $\chi^{2}$ test & $176.23 * * *$ & $48.65^{* * *}$ & $123.7 * * *$ & $2127.41 * * *$ & $9308.43 * * *$ & $564.85 * * *$ \\
\hline $\begin{array}{l}\text { Sargan Test } \\
\left(\chi^{2} \text { value }\right)^{8}\end{array}$ & $190.75 * * *$ & $52.55 * * *$ & $140.85 * * *$ & $357.82 * * *$ & $40.26^{* * *}$ & $254.09 * * *$ \\
\hline
\end{tabular}

\footnotetext{
${ }^{8}$ The Sargan test is employed to test the joint validity of GMM estimates. As the Sargan test (1958) implies, the instruments used are orthogonal to the error term.
} 
Table 12: Determinants of interest spreads and margins for PCBs

\begin{tabular}{|c|c|c|c|c|c|c|c|c|}
\hline \multicolumn{5}{|c|}{ Interest Spread } & \multicolumn{4}{|c|}{ Interest margin } \\
\hline & PCB & $\begin{array}{l}\text { PCB } \\
\text { (after } \\
1999 \text { ) }\end{array}$ & $\begin{array}{c}\text { PCB } \\
\text { NEW } \\
\text { BANKS }\end{array}$ & $\begin{array}{l}\text { PCB } \\
\text { OLD } \\
\text { (after } \\
1999)\end{array}$ & PCB & $\begin{array}{c}\text { PCB (after } \\
1999)\end{array}$ & $\begin{array}{l}\text { PCB (new } \\
\text { banks) }\end{array}$ & $\begin{array}{c}\text { PCB old } \\
\text { banks (after } \\
1999)\end{array}$ \\
\hline $\begin{array}{c}\text { Lagged } \\
\text { interest } \\
\text { spread }\end{array}$ & $\begin{array}{c}0.41 \\
(0.07)^{* * *}\end{array}$ & $\begin{array}{c}0.30 \\
(0.09)^{* * *}\end{array}$ & $\begin{array}{c}0.34 \\
(0.19)^{* *}\end{array}$ & $\begin{array}{c}0.46 \\
(0.07)^{* * *}\end{array}$ & $\begin{array}{r}-0.06 \\
(0.03)^{* * *}\end{array}$ & $\begin{array}{r}-0.08 \\
(0.03)^{* * *}\end{array}$ & $\begin{array}{r}0.02 \\
(0.02)\end{array}$ & $\begin{array}{r}0.70 \\
(0.04)^{* * *}\end{array}$ \\
\hline Overhead & $\begin{array}{c}16.08 \\
(7.58)^{* * *}\end{array}$ & $\begin{array}{c}16.75 \\
(9.60)^{*}\end{array}$ & $\begin{array}{c}20.53 \\
(20.18)\end{array}$ & $\begin{array}{c}3.52 \\
(8.20)\end{array}$ & $\begin{array}{r}0.32 \\
(0.25)\end{array}$ & $\begin{array}{r}0.32 \\
(0.31)\end{array}$ & $\begin{array}{r}0.94 \\
(0.22)^{* * *}\end{array}$ & $\begin{array}{r}-1.37 \\
(0.77)^{*}\end{array}$ \\
\hline $\begin{array}{l}\text { Capital } \\
\text { ratio }\end{array}$ & $\begin{array}{c}-0.85 \\
(1.16)\end{array}$ & $\begin{array}{l}-1.39 \\
(2.17)\end{array}$ & $\begin{array}{l}-0.89 \\
(8.93)\end{array}$ & $\begin{array}{c}0.39 \\
(1.07)\end{array}$ & $\begin{array}{r}0.14 \\
(0.04)^{* * *}\end{array}$ & $\begin{array}{r}0.00 \\
(0.05)\end{array}$ & $\begin{array}{r}0.96 \\
(0.11)^{* * *}\end{array}$ & $\begin{array}{r}0.09 \\
(0.11)\end{array}$ \\
\hline NPL & $2.49(1.65)$ & $\begin{array}{c}2.74 \\
(1.87)\end{array}$ & $\begin{array}{c}-0.04 \\
(10.53)\end{array}$ & $\begin{array}{c}1.91 \\
(1.43)\end{array}$ & $\begin{array}{r}0.00 \\
(0.04)\end{array}$ & $\begin{array}{r}0.07 \\
(0.05)\end{array}$ & $\begin{array}{r}-0.19 \\
(0.09)^{* *}\end{array}$ & $\begin{array}{r}-0.07 \\
(0.11)\end{array}$ \\
\hline Bank size & $1.17(0.98)$ & $\begin{array}{c}1.09 \\
(1.27)\end{array}$ & $\begin{array}{c}1.51 \\
(5.00)\end{array}$ & $\begin{array}{c}0.44 \\
(1.24)\end{array}$ & $\begin{array}{r}-0.54 \\
(0.03)^{* * *}\end{array}$ & $\begin{array}{r}-0.60 \\
(0.04)^{* * *}\end{array}$ & $\begin{array}{r}-0.19 \\
(0.06)^{* * *}\end{array}$ & $\begin{array}{r}-0.18 \\
(0.07)^{* * *}\end{array}$ \\
\hline $\begin{array}{l}\text { Other } \\
\text { income }\end{array}$ & $0.42(0.90)$ & $\begin{array}{l}-0.40 \\
(1.45)\end{array}$ & $\begin{array}{c}5.41 \\
(5.16)\end{array}$ & $\begin{array}{c}0.63 \\
(0.82)\end{array}$ & $\begin{array}{r}0.05 \\
(0.03)^{*}\end{array}$ & $\begin{array}{r}0.11 \\
(0.05)^{* * * *}\end{array}$ & $\begin{array}{r}0.13 \\
(0.05)^{* * *}\end{array}$ & $\begin{array}{r}0.07 \\
(0.11)\end{array}$ \\
\hline MSD & $\begin{array}{c}-9.57 \\
(13.23)\end{array}$ & $\begin{array}{l}-19.56 \\
(18.93)\end{array}$ & $\begin{array}{l}-205.56 \\
(314.46)\end{array}$ & $\begin{array}{c}-4.08 \\
(12.09)\end{array}$ & $\begin{array}{r}0.01 \\
(0.50)\end{array}$ & $\begin{array}{r}-0.08 \\
(0.76)\end{array}$ & $\begin{array}{r}1.03 \\
(2.18)\end{array}$ & $\begin{array}{r}-0.68 \\
(0.41)^{*}\end{array}$ \\
\hline HHI & $0.02(0.02)$ & $\begin{array}{c}0.01 \\
(0.03)\end{array}$ & $\begin{array}{c}0.08 \\
(0.62)\end{array}$ & $\begin{array}{c}0.04 \\
(0.02)^{* *}\end{array}$ & $\begin{array}{r}0.00 \\
(0.00)^{* *}\end{array}$ & $\begin{array}{r}0.00 \\
(0.00)^{* *}\end{array}$ & $\begin{array}{r}-0.02 \\
(0.00)^{* * *}\end{array}$ & $\begin{array}{r}0.00 \\
(0.00)\end{array}$ \\
\hline QI & $\begin{array}{c}0.00 \\
(0.00)^{* * *}\end{array}$ & $\begin{array}{c}0.00 \\
(0.00)^{* * *}\end{array}$ & $\begin{array}{c}0.00 \\
(0.00)\end{array}$ & $\begin{array}{c}0.01 \\
(0.00)\end{array}$ & $\begin{array}{r}0.00 \\
(0.00)\end{array}$ & $\begin{array}{r}0.00 \\
(0.00)\end{array}$ & $\begin{array}{r}0.00 \\
(0.00)\end{array}$ & $\begin{array}{r}0.00 \\
(0.00)\end{array}$ \\
\hline Inflation & $\begin{array}{c}-0.06 \\
(0.03)^{* *} \\
-0.24\end{array}$ & $\begin{array}{c}-0.10 \\
(0.05)^{* * *}\end{array}$ & $\begin{array}{l}-0.08 \\
(0.20)\end{array}$ & $\begin{array}{c}-0.06 \\
(0.03) * * * \\
-0.24\end{array}$ & $\begin{array}{r}0.00 \\
(0.00) \\
0.08\end{array}$ & $\begin{array}{r}0.00 \\
(0.00)\end{array}$ & $\begin{array}{r}-0.01 \\
(0.00)^{* * *}\end{array}$ & $\begin{array}{r}0.00 \\
(0.00)\end{array}$ \\
\hline FLI & $(0.31)$ & -- & -- & $(0.34)$ & $(0.01)^{* * *}$ & & & \\
\hline Tax & $\begin{array}{l}-3.03 \\
(2.91)\end{array}$ & $\begin{array}{l}-5.21 \\
(3.67)\end{array}$ & $\begin{array}{l}-18.58 \\
(20.35)\end{array}$ & $\begin{array}{l}-5.21 \\
(3.67)\end{array}$ & $\begin{array}{r}0.21 \\
(0.01)^{* * *}\end{array}$ & $\begin{array}{r}0.24 \\
(0.02)^{* * *}\end{array}$ & $\begin{array}{r}0.11 \\
(0.02)^{* * *}\end{array}$ & $\begin{array}{r}0.06 \\
(0.02)^{* * *}\end{array}$ \\
\hline LRR & $\begin{array}{c}-0.88 \\
(0.37)^{* * *}\end{array}$ & $\begin{array}{c}-0.81 \\
(0.44)^{* *}\end{array}$ & $\begin{array}{l}-0.20 \\
(1.75)\end{array}$ & $\begin{array}{c}-0.78 \\
(0.43)^{*}\end{array}$ & $\begin{array}{r}-0.01 \\
(0.00)^{* * *}\end{array}$ & $\begin{array}{r}-0.01 \\
(0.00)^{* * *}\end{array}$ & $\begin{array}{r}0.00 \\
(0.00)\end{array}$ & $\begin{array}{r}-0.01 \\
(0.00)^{* * *}\end{array}$ \\
\hline Bank Rate & $\begin{array}{l}-0.03 \\
(0.04)\end{array}$ & $\begin{array}{l}-0.02 \\
(0.04)\end{array}$ & $\begin{array}{c}-0.28 \\
(0.21)\end{array}$ & $\begin{array}{c}0.01 \\
(0.03)\end{array}$ & $\begin{array}{r}-0.51 \\
(0.11)^{* * *}\end{array}$ & $\begin{array}{r}-0.07 \\
0.17\end{array}$ & $\begin{array}{r}-0.75 \\
(0.19)^{* * *}\end{array}$ & $\begin{array}{r}-0.39 \\
(0.34)\end{array}$ \\
\hline Constant & $\begin{array}{c}7.76 \\
(4.58)^{*} \\
\end{array}$ & $\begin{array}{c}8.13 \\
(6.55) \\
\end{array}$ & $\begin{array}{c}-7.73 \\
(27.98) \\
\end{array}$ & $\begin{array}{c}12.63 \\
(5.51)^{* * *}\end{array}$ & $\begin{array}{r}1.43 \\
(0.17)^{* * *}\end{array}$ & $\begin{array}{r}1.41 \\
(0.20)^{* * *} \\
\end{array}$ & $\begin{array}{r}0.12 \\
(0.31) \\
\end{array}$ & $\begin{array}{r}0.85 \\
(0.45)^{* *}\end{array}$ \\
\hline $\mathrm{N}$ & 235 & 185 & 52 & 185 & 263 & 212 & 56 & 204 \\
\hline $\begin{array}{c}\text { Wald } \chi^{2} \\
\text { test } \\
\text { Sargan } \\
\text { Test }\left(\chi^{2}\right. \\
\text { value })\end{array}$ & $173.5 * * *$ & $128.79 * * *$ & 18.89 & $128.79 * *$ & $229.06^{* * *}$ & $473.65 * * *$ & $3181.33 * * *$ & $534.04 * * *$ \\
\hline
\end{tabular}


Table 13: Determinants of interest spreads and margins for SCBs

\begin{tabular}{|c|c|c|c|c|}
\hline & \multicolumn{2}{|l|}{ Interest Spread } & \multicolumn{2}{|c|}{ Interest margin } \\
\hline & All SCBs & $\begin{array}{c}\text { All SCBs after } \\
1999\end{array}$ & All SCBs & All SCBs after 1999 \\
\hline Lagged interest spread & $0.22(0.16)$ & $0.07(0.15)$ & $0.36(0.14) * * *$ & $0.14(0.16)$ \\
\hline Overhead & $23.48(12.65)^{* *}$ & $53.95(18.71)^{* * *}$ & $-0.03(0.14)$ & $-0.09(0.15)$ \\
\hline Capital ratio & $-3.89(2.66)$ & $-6.12(3.17)^{* *}$ & $-0.01(0.03)$ & $-0.03(0.03)$ \\
\hline NPL & $-0.35(1.27)$ & $-0.11(2.53)$ & $0.01(0.02)$ & $0.02(0.02)$ \\
\hline Bank size & $-5.54(1.63) * * *$ & $-6.36(4.61)$ & $0.01(0.04)$ & $-0.01(0.05)$ \\
\hline Non-interest income & $4.88(2.77)^{*}$ & $6.04(2.30) * * *$ & $-0.02(0.02)$ & $-0.01(0.02)$ \\
\hline MSD & $1.74(2.62)$ & $0.83(3.62)$ & $0.01(0.03)$ & $-0.04(0.04)$ \\
\hline HHI & $0.00(0.00)$ & $0.00(0.00)$ & $0.00(0.00)^{* * *}$ & $0.00(0.00)^{* *}$ \\
\hline QI & $0.00(0.00)$ & $0.00(0.00)$ & $0.00(0.00)$ & $0.00(0.00)$ \\
\hline Inflation & $0.09(0.04) * * *$ & $0.06(0.07)$ & $0.00(0.00)^{* *}$ & $0.00(0.00)$ \\
\hline FLI & $-0.17(0.29)$ & -- & $-0.01(0.01)$ & \\
\hline LRR & $1.25(0.65)^{* *}$ & $1.69(1.77)$ & $-0.01(0.02)$ & $0.01(0.02)$ \\
\hline Constant & $35.86(6.88)^{* * *}$ & $35.52(16.51)^{* * *}$ & $-0.02(0.15)$ & $0.02(0.17)$ \\
\hline $\mathrm{N}$ & 53 & 37 & 53 & 37 \\
\hline Wald $\chi^{2}$ test & $55.35 * * *$ & $35.55 * * *$ & $134.23 * * *$ & $80.3^{* * *}$ \\
\hline Sargan Test $\left(\chi^{2}\right.$ value $)$ & 40.81 & 31.18 & 41.36 & 28.32 \\
\hline
\end{tabular}


Figure 1. Trends in non-performing loan

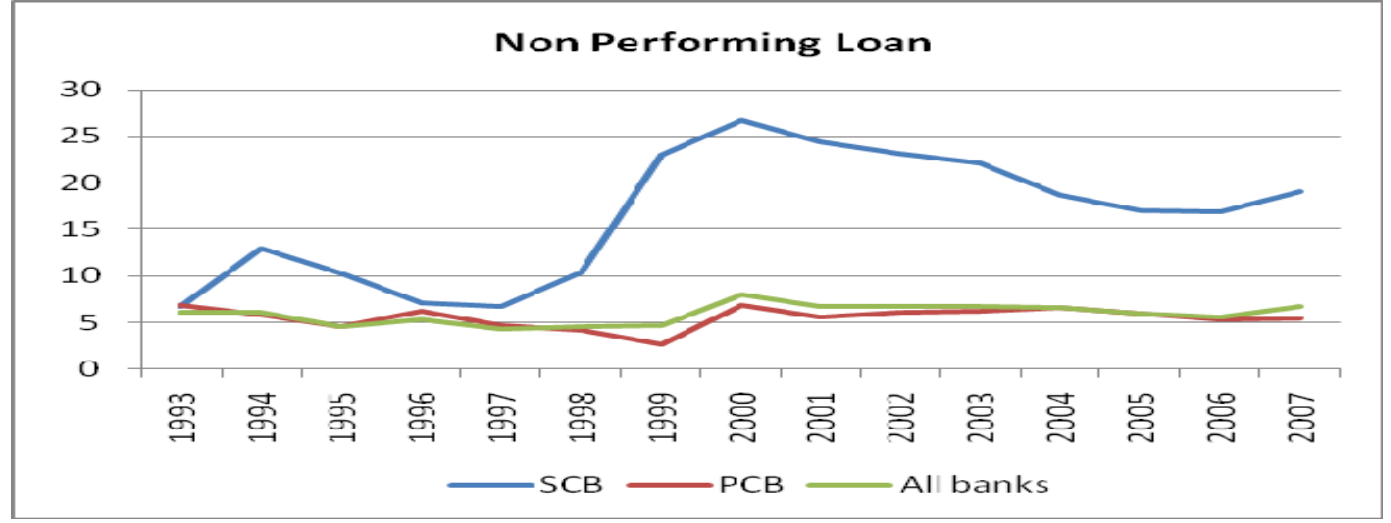

Figure 2: Commission and fees as \% of interest income

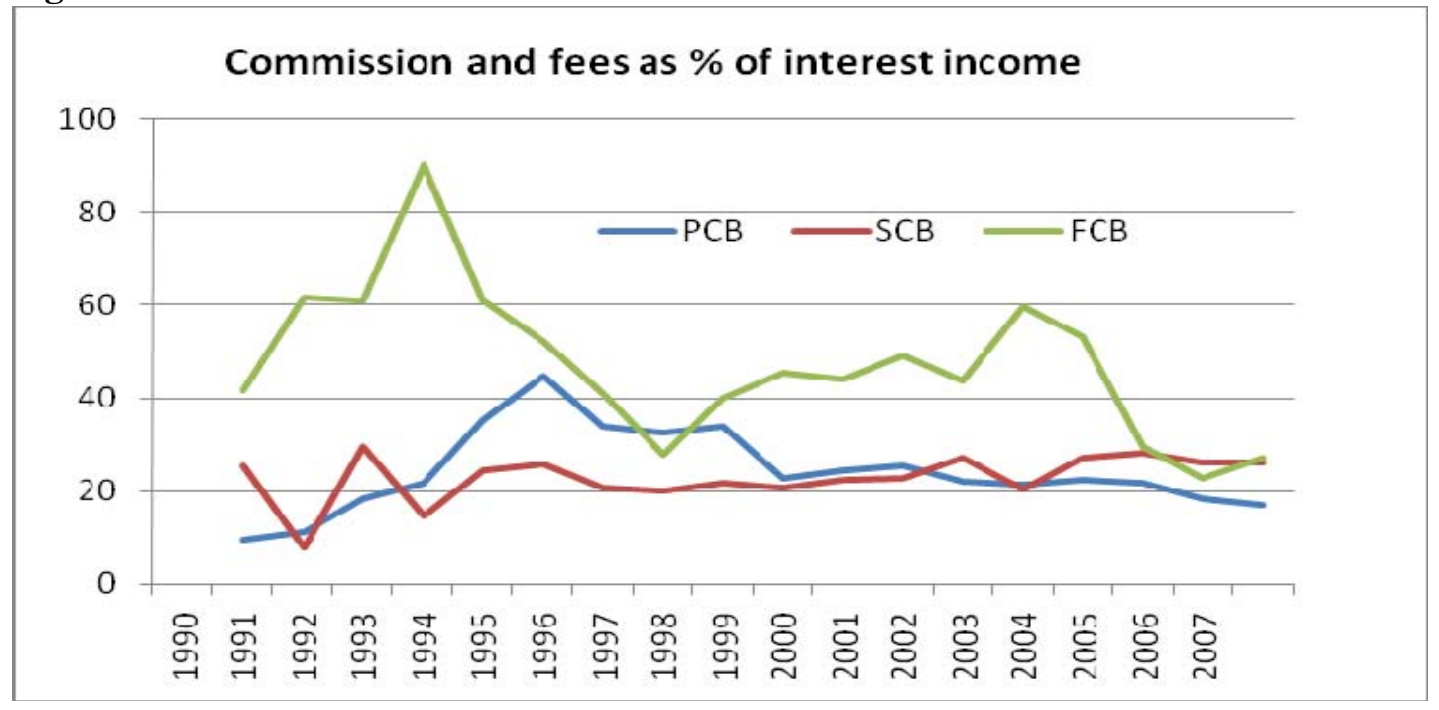


Figure 3(A). HH Index for loans

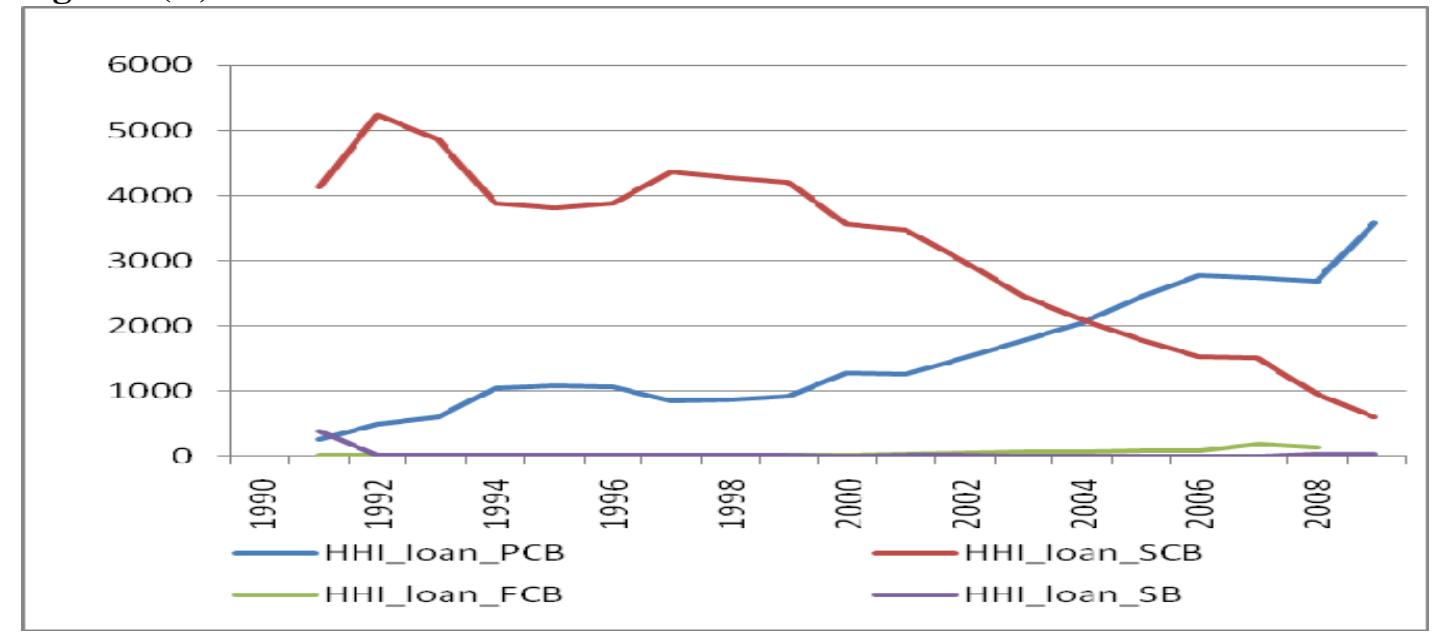

Figure 3(B): HH Index for deposits

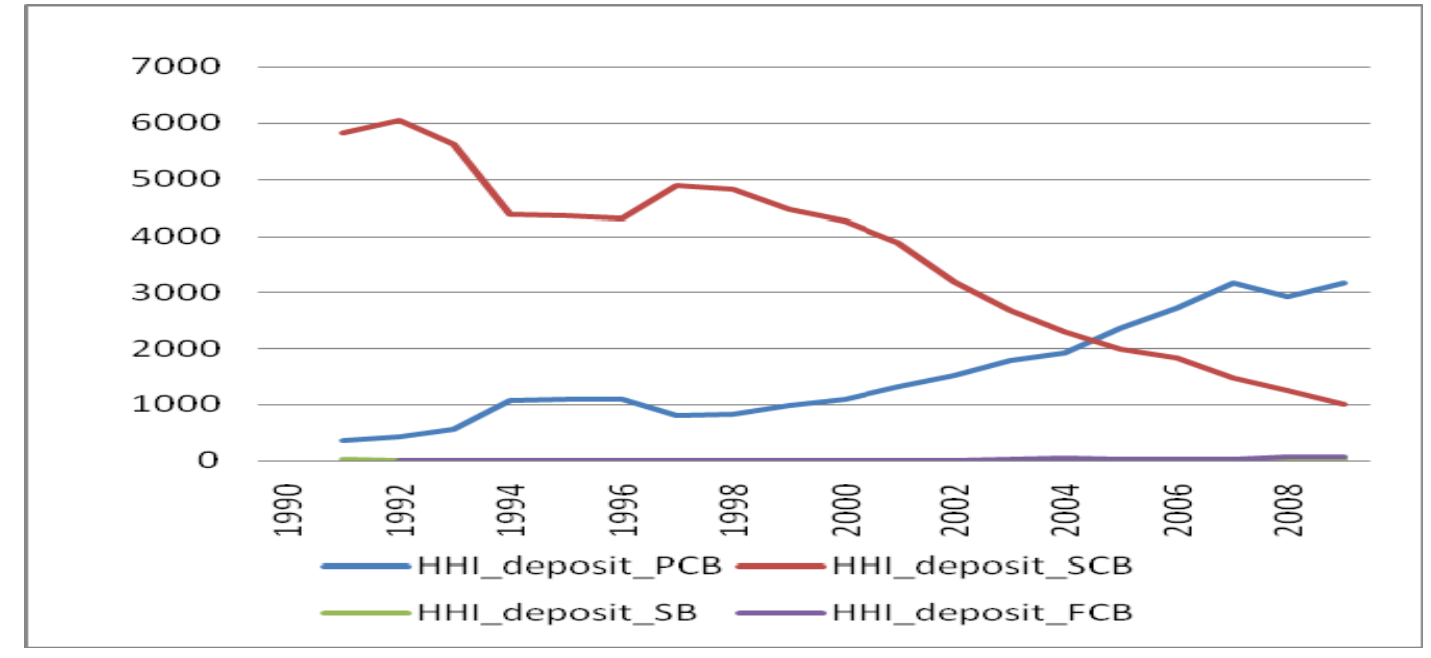

Figure 4A: Bank Interest Rate Spread in Bangladesh

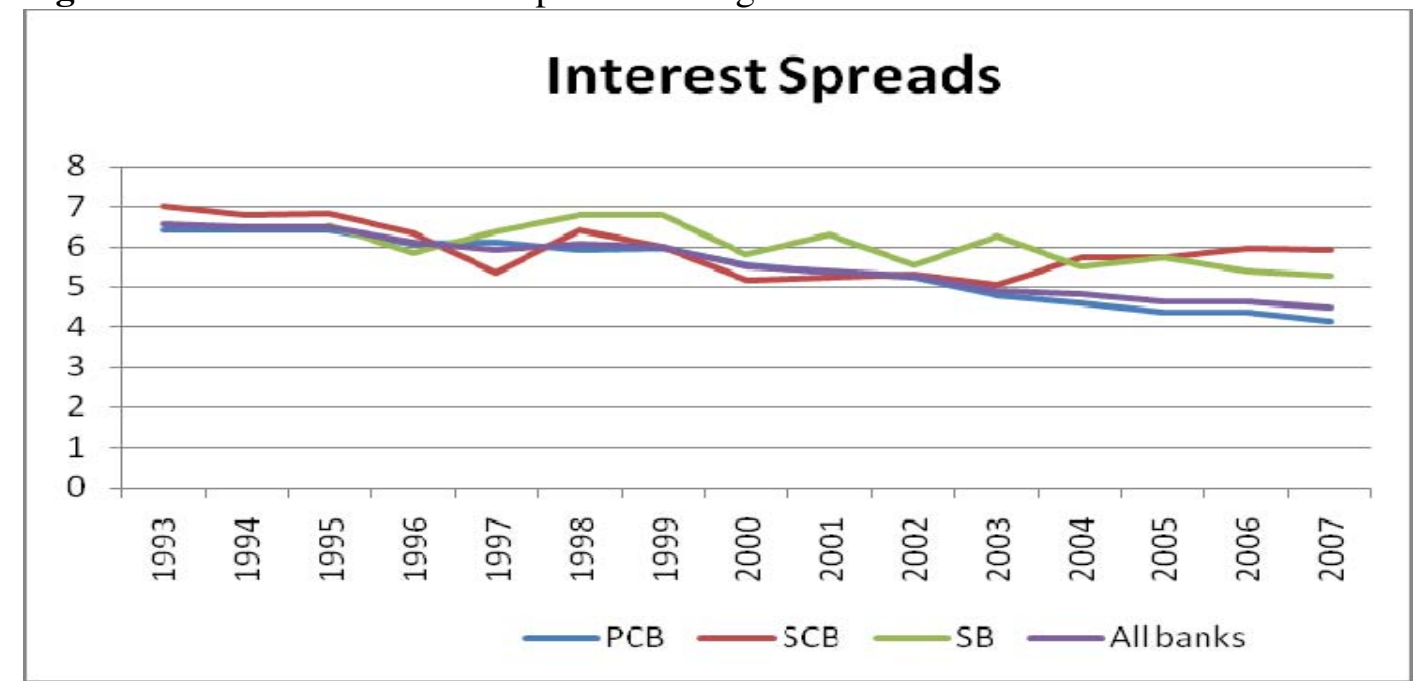


Figure 4B: Interest Rate Margin in Bangladesh

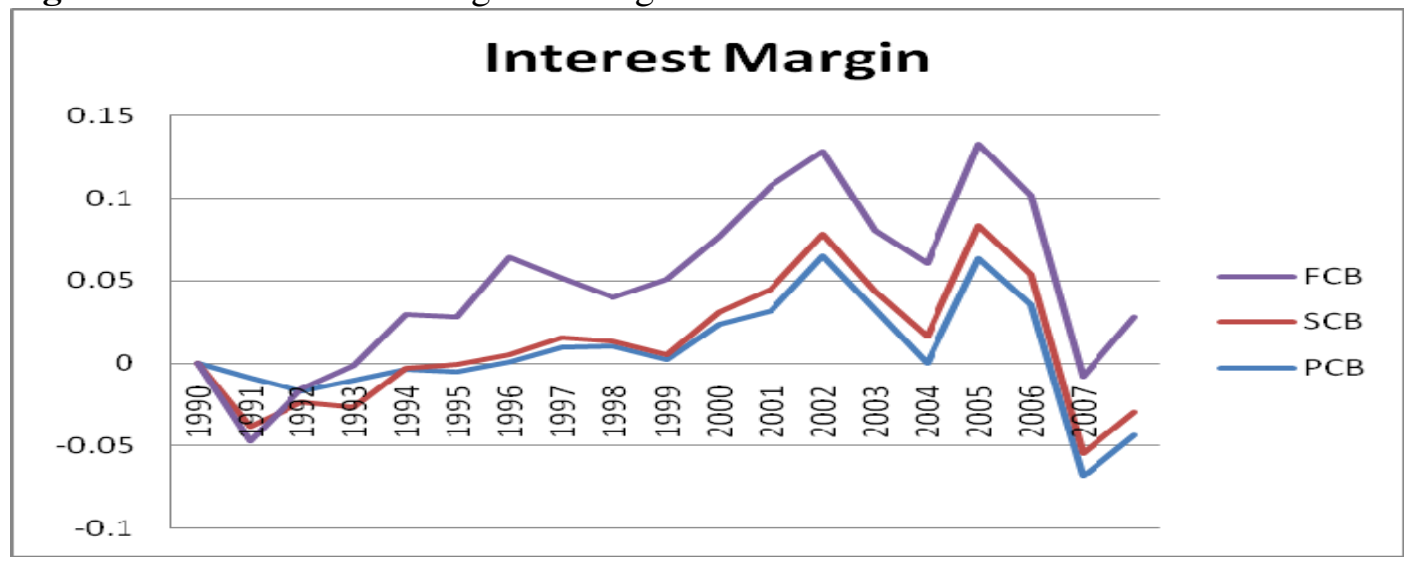

Figure 5. Impulse response of interest rates, loans and deposits

\section{Panel A}

Response to Cholesky One S.D. Innovations \pm 2 S.E.

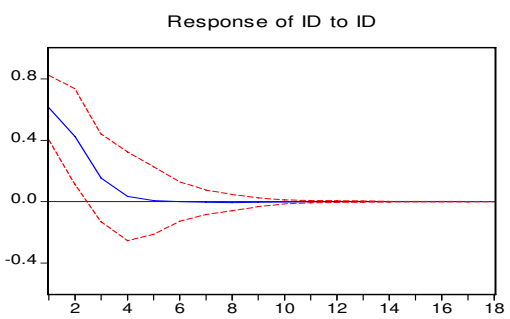

Response of ID to IL
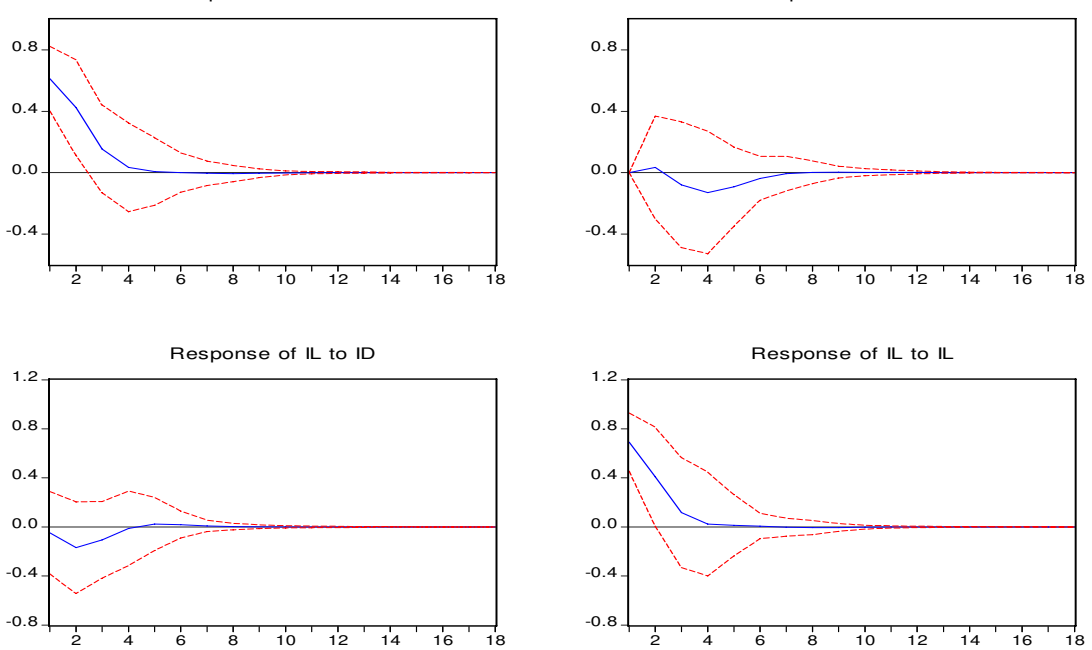

Panel B 
Response to Cholesky One S.D. Innovations \pm 2 S.E.

Response of ID to ID
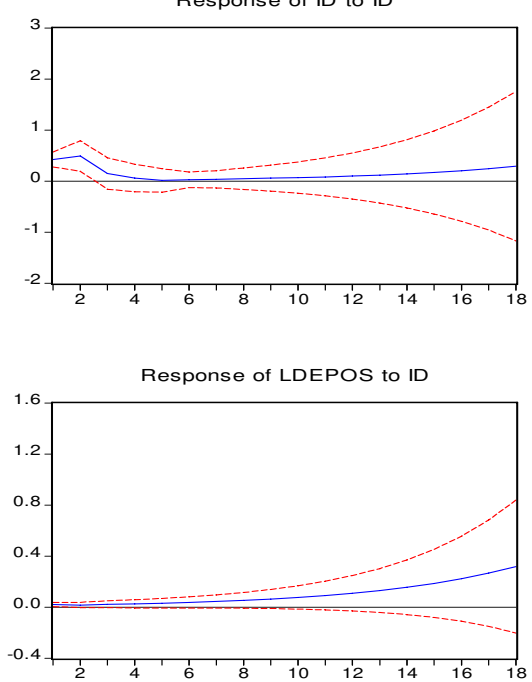

Response of ID to LDEPOS

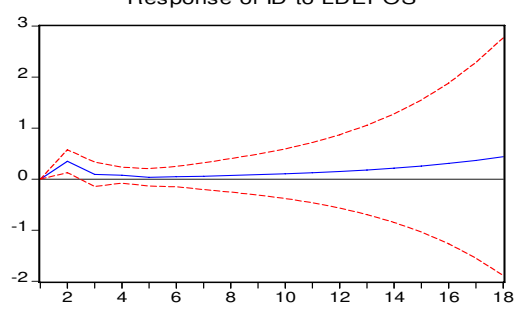

Response of LDEPOS to LDEPOS

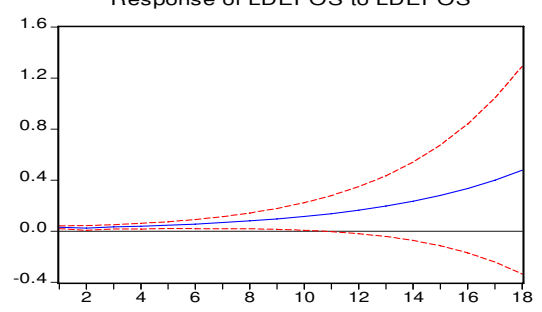

Panel C

Response to Cholesky One S.D. Innovations \pm 2 S.E.
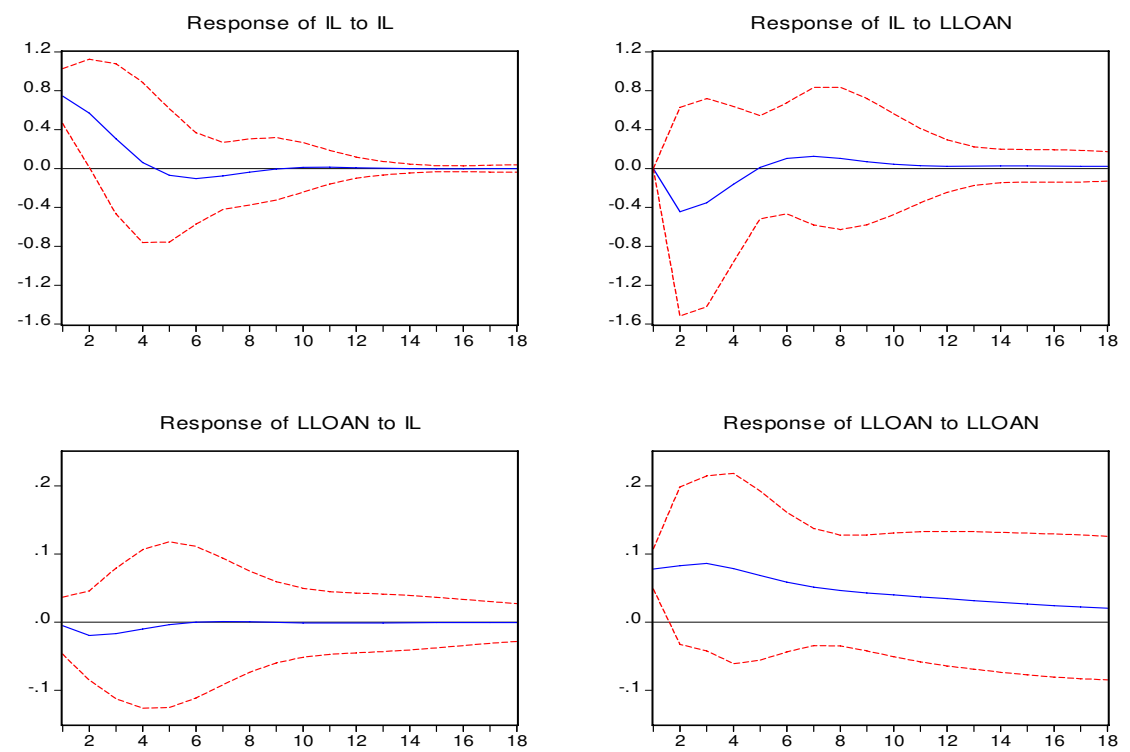
Table A1: List of Banks

\section{Appendix:}

\begin{tabular}{|c|c|c|c|}
\hline $\begin{array}{l}\text { State-owned Commercial } \\
\text { Banks (SCBs) }\end{array}$ & $\begin{array}{l}\text { Local Private Commercial Banks } \\
\text { (PCBs) }\end{array}$ & Foreign Commercial Banks (FCBs) & Specialized Banks (SBs) \\
\hline $\begin{array}{ll}\text { - } & \text { Agrani Bank Limited } \\
\text { - } & \text { Janata Bank Ltd } \\
\text { - } & \text { Sonali Bank Ltd } \\
\text { - } & \text { Rupali Bank Ltd. }\end{array}$ & $\begin{array}{l}\text { - BASIC Bank Limited } \\
\text { - Bangladesh Krishi Bank } \\
\text { - Bangladesh Shilpa Bank }\end{array}$ & 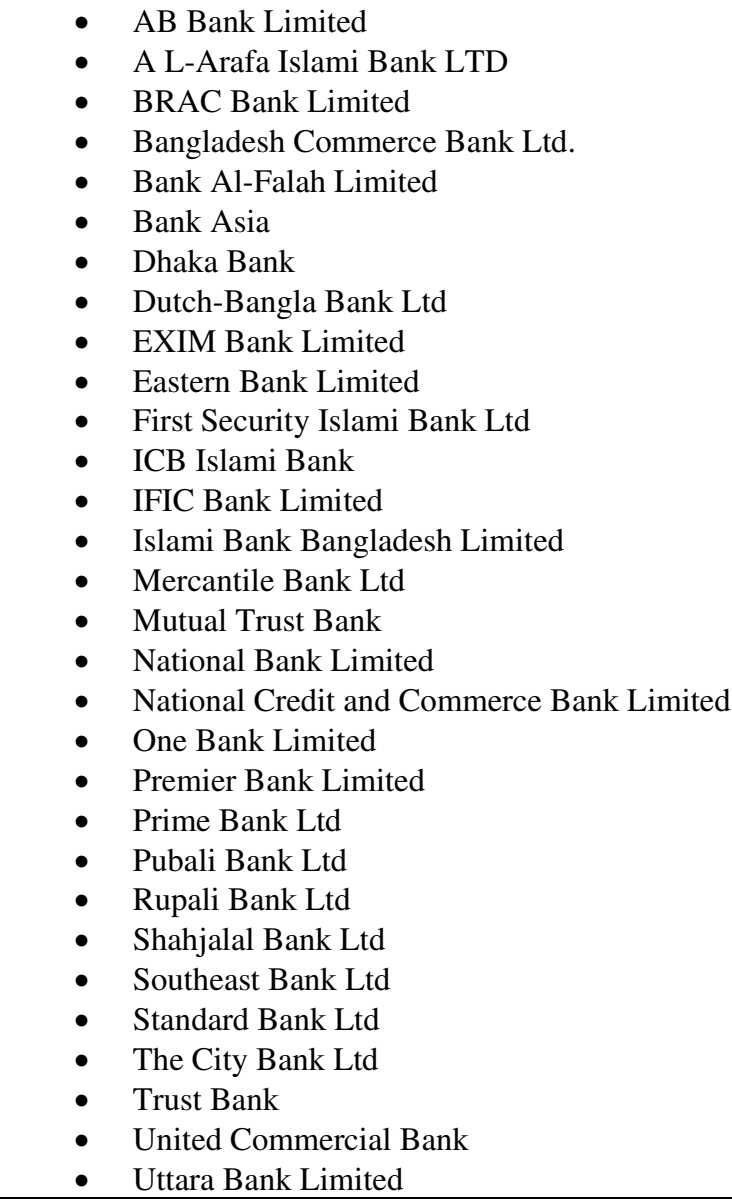 & $\begin{array}{ll}\text { - } & \text { Citibank N.A } \\
\text { - } & \text { Commercial Bank of Ceylon } \\
\text { - } & \text { Habib Bank Ltd } \\
\text { - } & \text { Standard Chartered Bank } \\
\text { - } & \text { State Bank of India } \\
\text { - } & \text { The Hong Kong and Sanghai Bank Ltd } \\
\text { - } & \text { Woori Bank }\end{array}$ \\
\hline
\end{tabular}

